\title{
Response Mechanisms of Bacterial Degraders to Environmental Contaminants on the Level of Cell Walls and Cytoplasmic Membrane
}

\author{
Slavomíra Murínová ${ }^{1,2}$ and Katarína Dercová ${ }^{1}$ \\ ${ }^{1}$ Department of Biochemical Technology, Faculty of Chemical and Food Technology, Institute of Biotechnology and Food Science, \\ Slovak University of Technology, Radlinského 9, 81237 Bratislava, Slovakia \\ ${ }^{2}$ Water Research Institute, Nábrežie arm. gen. L. Svobodu 5, 81249 Bratislava, Slovakia
}

Correspondence should be addressed to Slavomíra Murínová; slavomira.murinova@gmail.com

Received 14 February 2014; Revised 12 May 2014; Accepted 27 May 2014; Published 26 June 2014

Academic Editor: Hugh W. Morgan

Copyright (C) 2014 S. Murínová and K. Dercová. This is an open access article distributed under the Creative Commons Attribution License, which permits unrestricted use, distribution, and reproduction in any medium, provided the original work is properly cited.

\begin{abstract}
Bacterial strains living in the environment must cope with the toxic compounds originating from humans production. Surface bacterial structures, cell wall and cytoplasmic membrane, surround each bacterial cell and create selective barriers between the cell interior and the outside world. They are a first site of contact between the cell and toxic compounds. Organic pollutants are able to penetrate into cytoplasmic membrane and affect membrane physiological functions. Bacteria had to evolve adaptation mechanisms to counteract the damage originated from toxic contaminants and to prevent their accumulation in cell. This review deals with various adaptation mechanisms of bacterial cell concerning primarily the changes in cytoplasmic membrane and cell wall. Cell adaptation maintains the membrane fluidity status and ratio between bilayer/nonbilayer phospholipids as well as the efflux of toxic compounds, protein repair mechanisms, and degradation of contaminants. Low energy consumption of cell adaptation is required to provide other physiological functions. Bacteria able to survive in toxic environment could help us to clean contaminated areas when they are used in bioremediation technologies.
\end{abstract}

\section{Introduction}

Over hundreds of years, mankind has been producing millions of tons of dangerous pollutants. A significant part of this pollution consists of hydrophobic organic compounds that are extremely persistent. These compounds have been stored in soil and water sediments and tend to persist unmodified over decades. Nowadays, there is a growing awareness concerning the toxic or even carcinogenic effects of these chemicals. Efficient ways to dispose this waste are physical and chemical techniques that include combustion, photolysis, chemical degradation, and decomposition. Each chemical method can be successfully applied only within a certain range of concentrations of organic compounds due to their solubility, toxicity, and persistence [1]. Limitations of the application of these techniques in the environment are caused by low concentration of the pollutants. Alternative methods for the decontamination are represented by biodegradation or phytoremediation. Biodegradation has long been seen as a cost-effective and ecological way to eliminate environmental contamination [2]. However, the toxicity of the chemicals can hamper application of microorganisms for removal of the pollutants. Bacteria used for biodegradation must be able to survive and colonize the contaminated area. Some bacteria have developed efficient adaptation mechanisms to survive under adverse conditions [3-5]. Anomalies in environmental conditions activate in cells a series of processes that allow microorganisms to minimize their negative impact. All adaptation mechanisms are synchronized to ensure necessary physiological functions with low energy consumption. Environmentally induced perturbations in cell membrane structure may result in significant disturbance of some physiological functions. Flexibility and adaptation capacity of the membrane largely determines survival of 
the cells $[6,7]$. Since membranes constitute the main target for the action of solvents, most adaptive mechanisms are concerned with maintenance of the membrane fluidity and lipid-phase stability [8]. Fluidity of cytoplasmic membrane is a very important characteristic of the membrane structure and is defined as the reciprocal value of its viscosity. It can be modulated by the alteration of fatty acids that build membrane phospholipids.

\section{Cytoplasmic Membrane}

Cytoplasmic membrane is a dynamic structure, which consists of stable phospholipid bilayer with motile proteins. The lipid components of the membrane form a barrier to the transport of molecules, while protein components act as transport structures of pumps and channels that allow selected molecules to circulate into and out of the cell [9]. Cytoplasmic membranes of most bacterial strains consist of phosphatidylethanolamine-PE (75\%), phosphatidylglycerol-PG (15-20\%), and cardiolipin-CL (5-10\%). Unlike mammals, only a few bacterial species contain phosphatidylcholine (PC) in the membranes (e.g., Rhodopseudomonas sphaeroides, Pseudomonas stutzeri). These bacteria tend to be highly specialized or highly evolved. PC is synthesized by three successive methylations of PE [10].

Studies with E. coli showedthat bacterial phospholipids are synthesized exclusively for use in the biogenesis of membranes [11]. The enzymes of fatty acid biosynthesis are located in the cytoplasmic membrane, and the enzymes that metabolize phospholipids are bound to the inner part of the membrane. Biosynthesis of one mole of phospholipid from acetyl-CoA and sn-glycerol-3-phosphate requires $32 \mathrm{~mol}$ of ATP. Phospholipids constitute $10 \%$ of the dry weight of the cell, which means that a significant amount of energy expended in the biogenesis of a new cell is used in the production of membrane phospholipids $[10,12]$.

The diversity of cell membrane functions is conditioned by their structure. Despite their different functions, the membranes have according to Berg et al. [13] in common several similarities:

(1) membranes are sheet-like structures with the thickness between $6 \mathrm{~nm}$ and $10 \mathrm{~nm}, 60-100 \AA$, respectively. They form dosed boundariesbetween different compartments [13];

(2) membranes consist mainly of lipids and proteins with or without carbohydrate appendix. The mass ratio of lipids to proteins ranges from $1: 4$ to $4: 1$ [14];

(3) membrane phospholipids are molecules with average size about 10 angström. They have hydrophilic and hydrophobic moieties. Because of the differences in polarity of their constituents, they spontaneously form bimolecular sheets in aqueous environmentmembrane bilayers. The bilayers of lipids are barriers to the flow of polar molecules [15];
(4) membranes contain specific proteins, which mediate distinctive functions of particular membranes. Membrane proteins can have various functions, for example, receptors, membrane pumps, channels, energy transducers, and enzymes. Membrane proteins can be fully embedded in lipid bilayers or may stick out from the membrane structure [16];

(5) membranes are noncovalent cell components. The most abundant membrane elements, proteins, and phospholipids are linked together by noncovalent interactions, which act cooperatively $[16,17]$;

(6) membranes are in general asymmetric. The two faces of biological membranes always differ from each other [14];

(7) the fluidity is the most important membrane characteristic. Lipid molecules diffuse rapidly in the plane of the membrane, as do proteins, unless they are bonded by specific interactions. In contrast, lipid molecules and proteins do not readily rotate across the membrane. Membranes can be regarded as twodimensional bilayers of oriented proteins and lipids [13];

(8) most cell membranes are electrically polarized with a negatively charged inside (typically 60 millivolts). Membrane potential plays a key role in transport, energy conversion, and excitability $[13,14,16,17]$.

The most important function of cytoplasmic membrane of bacteria is to form a permeable barrier, regulating the passage of solutes between the cell and the outer environment. The membrane keeps essential metabolites and macromolecules inside the cell, it pumps nutrients into the cell against a concentration gradient, and it prevents the entry of certain compounds present in the environment $[12,18]$. The barrier properties of the cytoplasmic membrane are of special importance for the energy transduction of the cell [19].

2.1. Mechanism of Disturbance of the Cytoplasmic Membrane by Organic Compounds. Many organic pollutants are able to penetrate into cytoplasmic membrane resulting in swelling of the membrane and increase of membrane fluidity. This increase leads to the loss of membrane functionality and to the damage of bacterial cell. Heipieper et al. [3] established the existence of a systematic relationship between the values of $\log \mathrm{P}$ in the range 1-5 and values for the partitioning of solvents in cytoplasmic membrane. When a solvent penetrates into a membrane, it disturbs the integrity of that membrane and, hence, its function leads to an uncontrolled proton and potassium ions efflux. This leakage causes a lowering in the proton-motive force and leads to an impairment in the energy conservation $[20,21]$. The experiments with nine solvents (benzene, toluene, ethylbenzene, o-xylene, cyclohexane, naphthalene, biphenyl, $\alpha$-pinene, and decalin), each with $\log P$ values between 2 and 5, confirmed that their concentration in the membrane of up to $0.5 \mu \mathrm{mol} \cdot \mathrm{mg}^{-1}$ phospholipid resulted in an increase in the surface area of the membrane [21]. This partitioning level corresponds with approximately one solvent molecule per two phospholipid molecules. 
As a consequence, membrane fluidity is affected. Bacterial cells try to undertake appropriate responses to minimize disruptive effect of organic compounds by readjustment of fluidity.

\section{Adaptation Mechanisms of Bacterial Strains}

Membrane fluidity is the most important parameter that determines cell viability. Bacterial cells can change the fluidity of this surface component depending on the outer conditions. This could be performed by the alteration of fatty acid composition, their chain length, and phospholipid composition [22]. Most bacteria are resisting the fluidizing effect of hydrophobic compounds by changing their membrane composition to reduce fluidity and to maintain balance between bilayer and nonbilayer forming phospholipids [23]. These adaptation mechanisms rely on a modification of the membrane phospholipids. The alterations in the cytoplasmic membrane composition play crucial role in adaptation to the presence of high concentrations of toxic contaminants. Changes in the fatty acid composition of membrane lipids are the most important reactions of bacteria against membrane active substances. Most adaptive mechanisms were only described for Gram-negative $\left(\mathrm{G}^{-}\right)$aerobic bacteria $[19,24-$ 28]; however, some papers describing Gram-positive $\left(\mathrm{G}^{+}\right)$ aerobic [29-36] and anaerobic bacteria are also available [37, 38]. The last mentioned group of bacteria is rarely studied. The first systematic approach of anaerobic bacteria was published by Duldhardt et al. [38]. It demonstrates that anaerobic bacteria were about three times more sensitive towards a series of different organic compounds when compared with aerobic bacteria. This behavior was explained by a lower growth rate of anaerobic bacteria in comparison with aerobic species.

\subsection{Changes in Fatty Acids Composition}

3.1.1. Rigidification of Cytoplasmic Membrane. Segura et al. [39] mentioned that the alteration of the ratio of long-chain to short-chain fatty acids is involved in the regulation of the membrane fluidity under adverse conditions. Larger share of long-chain fatty acids can impede the pollutant penetration into the membrane. This results in lower concentration of the pollutant in the membrane and, thus, reduces its toxicity. However, increase of membrane saturation (rigidification) is a more efficient mechanism. Increase in saturation of membrane phospholipids in the presence of toxic organic compounds has been described in several publications [25, $26,40,41]$. The $\mathrm{IC}_{50}-\mathrm{IC}_{75}$ concentration of toxic compound leads to the highest increase in membrane saturation [3, 38]. Previous reports indicated that aromatic compounds such as benzene, biphenyl, phenol, PCBs, and toluene can accumulate in membrane bilayer between the acyl chains of fatty acids. This phenomenon leads to the higher membrane fluidity. Bacterial cells try to counteract this effect with closer packing of fatty acid alkyl chains of the phospholipids in the cell membrane to increase the membrane rigidity and prevent the solvent accumulation $[19,21,38,42]$. The same mechanism was observed in Pseudomonas stutzeri in the presence of naphthalene. The increasing degree of membrane lipid saturation is one of the major adaptive mechanisms of bacteria cells to the presence of many aromatic compounds $[3,43,44]$. This alteration helps cells survive under longterm adverse conditions. The reasons for the ability of tightly packing saturated fatty acids are their spherical conformation (Figure 1(a)) and high phase transition temperatures $\left(T_{M}\right)$. Weber and de Bont [45] characterized the transition from the ordered phase (gel) into disordered phase (liquidcrystalline) $\left(T_{M}\right)$ and described the location of phospholipids in membrane. $T_{M}$ for long-chain saturated fatty acids are very high (e.g., for palmitic acid, it is $63^{\circ} \mathrm{C}$ ). This means that palmitic acid stays in ordered phase below $63^{\circ} \mathrm{C}$. Similarly, other long-chain saturated fatty acids contribute to low fluidity of membrane and increase membrane ordering under growth temperatures. This arrangement prevents fluidizing compounds to accumulate in membrane fractions. The corresponding monounsaturated fatty acids have lower $T_{M}$. The lowest $T_{M}$ was measured for unsaturated fatty acids with cis configuration of double bond; for example, for C16:1cis, it was $0^{\circ} \mathrm{C}$; for C16:1trans, it was $33^{\circ} \mathrm{C}$ [46-48]. Bacterial cells try to increase membrane rigidity to counteract the fluidization effect of organic pollutants. This will be provided with specific amount of fatty acids contributing to a lower $T_{M}$ and others to a higher $T_{M}$. The average composition will result in an average $T_{M}$.

The mechanism of increase of saturation degree has limitation due to the condition of synthesis of saturated fatty acids. In $\mathrm{G}^{-}$bacteria, only the energy-dependent de novo biosynthesis of saturated fatty acids allows for an increase in the degree of saturation with increasing the proportion of saturated to unsaturated fatty acids. Under growth-inhibiting conditions, lipid biosynthesis is stopped due to stringentresponse regulation, and that is why only growing cells can perform such kind of membrane adaptation $[38,49]$.

Contrast decrease in membrane saturation can be observed in the presence of polar solvents. Polar solvents are able to incorporate into membrane between the phospholipid headgroups and stimulate the formation of micellar structures. Therefore, microorganisms increase the production of unsaturated fatty acids at the expense of saturated fatty acids. This mechanism was observed in Escherichia coli in the presence of ethanol [50].

3.1.2. Isomerization of Unsaturated Fatty Acids. Two different groups of unsaturated fatty acids take part in bacterial adaptation to organic pollutants. Isomerization of $c$ is unsaturated fatty acids into correspondent trans isomers was described in many papers as adaptation mechanism of the bacterial cells under growth inhibiting conditions $[25,38,51,52]$. This mechanism is a short-term response triggered in the presence of hydrophobic chemicals that do not need to synthetize new fatty acids.

Various bacterial strains, for example, Pseudomonas and Vibrio, can adapt to the presence of toxic compounds and their fluidizing properties by isomerization of $c$ is unsaturated fatty acids to their appropriate trans isomers (Figures 1(b) and 1(c)). These two forms of unsaturated fatty acids have different 

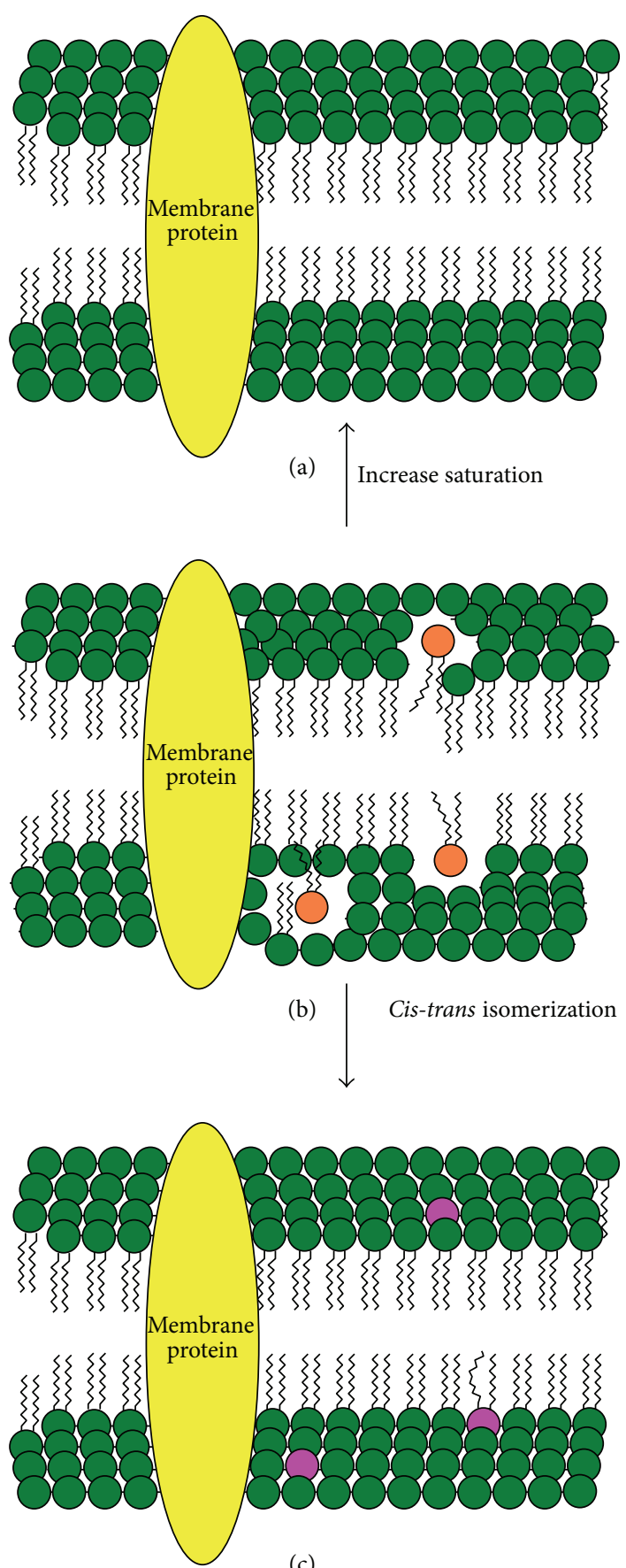

(c)

FIGURE 1: Two mechanisms increasing bacterial membrane saturation and decreasing membrane fluidity. The first one (direction from (b) to (a)) describes the increase of the synthesis of saturated fatty acids (green circles) instead of cis unsaturated fatty acids (orange circles); the second one (from (b) to (c)) shows the isomerization of cis unsaturated fatty acids into corresponding trans isomers (purple circles).

steric structure. The cis configuration of the acyl chain has a nonmovable bend of $30^{\circ}$, which causes steric hindrance and disturbs the highly ordered fatty acid package [51]. In contrast, the steric behavior of trans fatty acids and saturated fatty acids is very similar. Nonmovable bends of trans fatty acids have $6^{\circ}$. Both trans and long-chain saturated fatty acids possess a long extended conformation. It enables them to adopt a denser packing in the cytoplasmic membrane and allows protecting membrane against the fluidizing molecules. That is the reason why the transformation of cis to trans fatty acid leads to the decrease of membrane fluidity. Another reason for an ordered packing of trans fatty acids compared to $c i s$ isomers is their higher melting temperature $\left(T_{M}\right)$.

The studies involving toluene adapted Pseudomonas putida strain revealed higher amount of trans fatty acids. $T_{M}$ of cytoplasmic membrane of this strain was 7-9 Kelvin 
higher in comparison with nonadapted strain. Toluene can decrease lipid ordering with its fluidizing effect and promote the formation of an inverted hexagonal lipid. The observed conversion of cis unsaturatedfatty acids into trans fattyacids in $P$. putida is expected to counteract the formation of a nonbilayer structure. This observation can be rationalized because the lipid volume of the trans fattyacids is smaller than the cis isomer [8]. Heipieper et al. [52] proved the activation of the cis-trans isomerase in resting cells by the addition of 3-nitrotoluene. This activation resulted in the conversion of the cis unsaturated fatty acids into the corresponding trans isomers. The intensity of the rate of cis-trans isomerization depended on the added amount of toxic compound. A mutual dependency was found between the activation of this system and the induction/activation of other stress-response mechanisms [53]. Cis-trans isomerization correlates with the toxicity and amount of hydrophobic compound accumulated in cytoplasmic membrane. In most bacteria, the cis-trans isomerization is conducted by the transformation of oleic and vaccenic acids to their trans isomers in consequence of the high prevalence of the acids in cytoplasmic membrane [54].

The enzyme that is responsible for this adaptation mechanism, isomerase, belongs to cytochrome c-type protein and carries Cti polypeptide with a heme-binding site. This polypeptide was found in all tested Pseudomonas strains. Moreover, comparison of the amino acid sequences of the seven known Cti proteins identified it as heme containing protein [55]. Cti polypeptide is responsible for the localization of cis-trans isomerase in periplasmic space. That is the reason why only fatty acids with cis double bond in specific depth of membrane can reach the active site of isomerase [56]. This enzyme has been purified from the periplasmic fraction of Pseudomonas oleovorans for the first time by Pedrotta and Witholt [57]. The cis-trans isomerase gene cloned and sequenced from Pseudomonas putida P8 [54] and Pseudomonas putida DOT-T1E [58] made evident that the isomerase has an $\mathrm{N}$-terminal hydrophobic signal sequence. This sequence is cleaved off after targeting the enzyme to the periplasmic space. The observations confirmed that cis-trans isomerase is constitutively present, does not require ATP or other cofactors including $\mathrm{NAD}(\mathrm{P}) \mathrm{H}$ and glutathione, and works in the absence of de novo synthesis of lipids [20,49, 59, $60]$. The occurrence of heme-binding site of the cytochrome c-type strongly supports a mechanism of cis-trans isomerization by forming an enzyme-substrate complex. This finding prefers a mechanism for the enzyme, in which electrophilic iron $\left(\mathrm{Fe}^{3+}\right)$, provided by a heme domain, directly attacks cis double bond of fatty acid and removes an electron of the cis double bond, thereby transferring the $\mathrm{sp}^{2}$ linkage into $\mathrm{sp}^{3}$. Double bond is then rebuilt in trans configuration. Cis-trans isomerization is an exergonic (exothermic) reaction because the energetic difference between cis and trans configuration is $3.1 \mathrm{~kJ} \cdot \mathrm{mol}^{-1}[52]$.

3.1.3. Changes in Cyclopropane and Branched Fatty Acids. Higher concentration of organic pollutants stimulated production of cyclopropane fatty acids (C17-CP and C19-CP) in some bacterial strains. These results were observed under the exposure of polycyclic aromatic hydrocarbons (PAHs), phenols, biphenyl, and polychlorinated biphenyls (PCBs) [7, $28,61,62]$.

The role of these fatty acids in membrane adaptation mechanisms is still not clear because their participation in membrane permeability and fluidity maintenance is not understood in detail [63]. However, it was suggested that the presence of cyclopropane fatty acids in membrane may decrease membrane permeability to protons. Some authors indicated that cyclopropane fatty acid formation is one of the most important mechanisms that protect bacterial cells against many chemicals (aromatic compounds, organic solvents, alcohols, etc.) and environmental factors (salinity, pressure, and temperature) [6, 24, 48, 64-67].

Other authors demonstrated the decrease of the production of these fatty acids after the incorporation of toxic compounds into cultivation media [26, 42, 68]. Perly et al. [69] described poorly packing cyclopropane fatty acids into the acyl chain array of the phospholipid bilayer compared to unsaturated fatty acids. Even low content of cyclopropane fatty acids in cytoplasmic membrane may change overall mobility and order of the acyl chains. These fatty acids are formed from cis unsaturated fatty acids under energy consumption. It is thought that the primary function of cyclopropane fatty acids formation is to change chemical properties of the membrane without changes of physical properties [70]. The physiological role of cyclopropane fatty acids in survival of Escherichia coli under acid stress conditions was reported [63].

The abundance of branched fatty acids in FAMEs profiles obtained from contaminated environment strains is significantly higher compared to control samples [26, 71].

Lipids of anaerobic and $\mathrm{G}^{+}$aerobic bacteria often contain a high proportion of iso and anteiso branched fatty acids. Nevertheless, they can be found in several $\mathrm{G}^{-}$strains $[26,28]$. The maintenance of membrane fluidity with alteration of branched fatty acids depends on the energetic status of the cells as well as on de novo synthesis of their precursorsvaline (iso-branched-even-chain), leucine (iso-branchedodd-chain), and isoleucine (anteiso-branched-odd-chain). Iso and anteiso fatty acids show different physicochemical properties because of the differences in structure and $T_{M}$ $[10,13,38,72,73]$. The $T_{M}$ of the branched fatty acids is lower for the anteiso fatty acids (e.g., $51.7^{\circ} \mathrm{C}$ for $\mathrm{C} 15: 0$ iso and $23.0^{\circ} \mathrm{C}$ for $\mathrm{C} 15: 0$ anteiso) [72]. This difference causes a remarkable change in the fluidity of the membrane when the species of branched fatty acids are changed from one to the other and affect the lipid ordering in particular membrane fraction. The effect on $T_{M}$ caused by a change from anteiso- to isobranching in $\mathrm{G}^{+}$bacteria is comparable to the isomerization of cis to trans unsaturated fatty acids in $\mathrm{G}^{-}$bacteria. Even the volume occupied with anteiso fatty acids is higher than that occupied with iso fatty acids. $\mathrm{G}^{+}$and $\mathrm{G}^{-}$bacteria that contain branched fatty acids adapt to differences in temperature and organic solvents by altering the anteiso/iso ratio in the cell membrane. According to the different physicochemical properties of those two species of branched fatty acids, the bacteria showed a decreased amount of anteiso fatty acids when grown under adverse conditions to decrease the fluidity 
<smiles>[R]C(=O)OCC(COP(=O)([O-])OCC[NH3+])OC([R])=O</smiles>

(a)

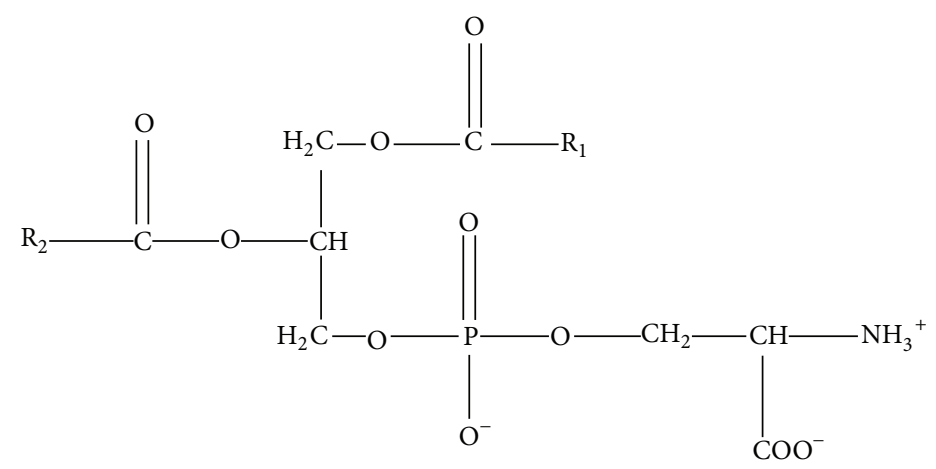

(b)<smiles>[R]C(=O)OCC(COP(=O)([O-])OCC[NH3+])OC([R])=O</smiles>

(c)<smiles>[R]C(=O)OCC(COP(=O)([O-])OCC(O)CO)OC([R])=O</smiles>

(d)<smiles>[R]C(=O)OCC(COP(=O)([O-])OCC(O)COP(=O)([O-])OCC(COC([R])=O)OC([R])=O)OC([R])=O</smiles>

(e)

FIGURE 2: Structure of bacterial membrane phospholipids-phosphatidylcholine (a), phosphatidylserine (b), phosphatidylethanolamine (c), phosphatidylglycerol (d), and cardiolipin (e). $\mathrm{R}_{1}, \mathrm{R}_{2}, \mathrm{R}_{3}$, and $\mathrm{R}_{4}$ represent fatty acid acyl chains.

of membrane and diminish incorporation of the pollutants into membrane structures $[28,62,73]$.

Anaerobic sulphate-reducing bacteria contain predominantly anteiso-branched fatty acids. The modification of their membrane fluidity is performed by increasing the relative ratio of saturated to anteiso-branched fatty acids. Under the growth insufficient conditions, this mechanism does not take place. The growth rate of anaerobic bacteria is much slower compared to that of the aerobic; therefore, the adaptation mechanisms take more time and these bacteria are sensitive to organic compounds to a higher extent than aerobic bacteria [74].

3.2. Changes in Phospholipids. Bacteria contain in their cytoplasmic membrane several different phospholipid headgroups (phosphatidylserine-PS, PC, PE, PG, and CL)
(Figure 2). Each of them holds specific function to maintain vital cell. In the presence of environmental perturbations, cells alter phospholipids amount.

Changes in phospholipids headgroups on environmental pollution are poorly studied compared to fatty acids alteration. Phosphatidylethanolamine (PE) is the most abundant phospholipid in bacterial membrane that comprises more than $70 \%$ of all phospholipids [13]. It provides lateral pressure to bacterial membrane bilayer and keeps the position of amino acids. It is a nonbilayer forming lipid because of its steric conformation (small glycerol group and high acylchain volume). Nonbilayer aggregates (preferred hexagonal conformation) of cytoplasmic membrane are important in cell division, membrane fusion, and lateral proteins and lipids motion. The ratio between bilayer and nonbilayer forming lipids varies in response to environmental changes. 
Organic solvents like benzene and toluene can reduce the transition temperature of membrane lamellar-gel to liquidcrystalline phase $\left(T_{M}\right)$ and enhance the formation of nonbilayer aggregates with decreasing $T_{\mathrm{LH}}$ temperature (transition from bilayer into hexagonal phase). Stabilization of the $T_{M}$ temperature is important to sustain membrane fluidity and stability. $T_{M}$ of cytoplasmic membrane can be slightly modified by membrane phospholipids (each of them has different $T_{M}$ ), which can affect bilayer stability of membrane (e.g., dipalmitoyl-PC has $41^{\circ} \mathrm{C}$, dipalmitoyl-PE has $63^{\circ} \mathrm{C}$, dipalmitoyl-PS has $55^{\circ} \mathrm{C}$, and dipalmitoyl-PG has $41^{\circ} \mathrm{C}$ $T_{M}$ ). Cultivation of Pseudomonas putida S-12 with toluene decreased amount of PE and increased content of PG and CL. This alteration could stabilize membrane by lowering the fluidity [39]. However, Weber and de Bont [45] described that phospholipids have much higher effect on bilayer stability $\left(T_{\mathrm{LH}}\right)$ than on membrane fluidity $\left(T_{M}\right)$ because of their ability to form hexagonal or lamellar structures. Based on these facts, the decrease of PE content leads to higher bilayer stability. Nevertheless, bacterial cell tries to keep balance between bilayer and nonbilayer phospholipids to maintain its physiological function.

Donato et al. [29] described the effect of DDT on the bacterial strain Bacillus stearothermophilus. This compound induced a very significant increase of the PE membrane content with a parallel decrease of PG content. This alteration was accompanied by an increase of straight chains and parallel decrease of branched fatty acids in cytoplasmic membrane. DDT promoted more ordered membrane with an increase of the $T_{M}$ temperature to higher values that led into higher membrane rigidity. However, increase in PE and decrease of PG amounts are not usual responses of the bacteria. PG is important in CL synthesis and plays a role in protein translocation across the membrane [10].

Based on their polarity, toxic organic solvents can accumulate in different membrane sites. This affects their ability to change membrane bilayer stability by the formation of inverted cone (polar pollutants) or cone structures (nonpolar pollutants). Polar compounds as ethanol can accumulate between the glycerol headgroups. This process destabilizes bilayer-nonbilayer balance. Bacterial cells react to this effect by the formation of a lipid with a small headgroup volume, for example, monoglucosyldiglyceride (MGDG). Benzene, for example, increases hexagonal aggregates. Cells counteract this phenomenon by stimulation of production of lamellar phospholipids (e.g., diglucosylglyceride, DMGM). A similar effect can be observed in the presence of toluene. Toluene is able to incorporate into the membrane between the acyl chains. The cell response is to produce higher amount of CL to stabilize bilayer. CL has a larger headgroup volume compared to PE. The decrease of PE production and increase of CL content will increase the volume of headgroups. This can compensate toluene induced increase of acyl chains volume and stabilize bilayer. Moreover, CL has 10-Kelvin higher $T_{M}$ than PE. Due to this fact, CL increases membrane rigidity while toluene induces disordering of acyl chains. As mentioned above, an opposite effect occurs in the presence of polar ethanol [68].

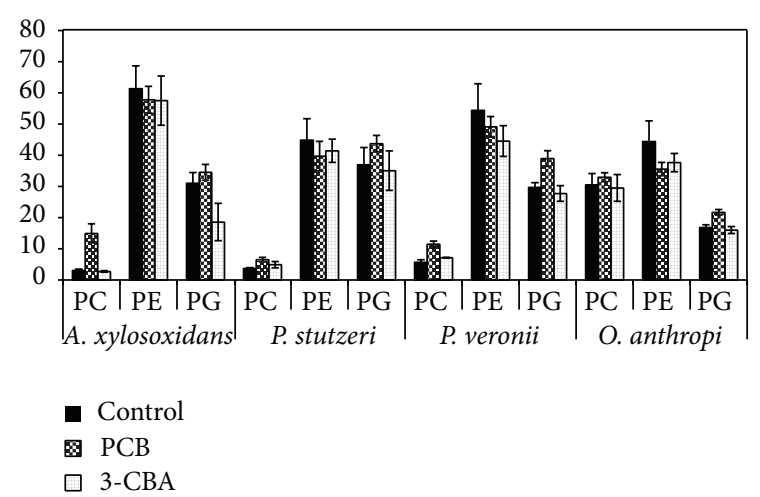

FIGURE 3: Percentage representation of membrane phospholipids after the addition of nonpolar (PCBs) and polar (3-CBA) toxic pollutants in the presence of four bacterial strains isolated from a long-term PCB-contaminated soil and sediment: Alcaligenes xylosoxidans, Ochrobactrum anthropi, Pseudomonas stutzeri, and Pseudomonas veronii. PC: phosphatidylcholine, PE: phosphatidylethanolamine, and PG: phosphatidylglycerol.

The regulation of phospholipid headgroups content controls the ratio between bilayer and nonbilayer membrane structures and the bilayer surface charge density. The accumulation of organic solvents in the lipid bilayer may increase the distance between the lipids in the bilayer. These changes of the phospholipids will affect the surface charge density of the membrane. Similarly, ethanol increases lipids surface area. PS present in cytoplasmic membrane counteracted this effect and provided lower ethanol sensitivity of E. coli. PE and PC showed no effect on cell resistance. The explanation for bacterial resistance to environmental stress is an increase in anionzwitterionic phospholipid ratio observed by Romantsov et al. [75].

The effect of nonpolar PCBs and polar 3-chlorobenzoic acid (3-CBA) was assessed in our laboratory using four bacterial isolates. The initial concentration of $100 \mathrm{mg} \cdot \mathrm{L}^{-1}$ of each pollutant was added into the minimal mineral media at the beginning of cultivation together with the bacterial inoculum $\left(1 \mathrm{~g} \cdot \mathrm{L}^{-1}\right)$. Adaptation responses in phospholipid headgroups were analyzed after six days of cultivation on the rotary shaker $(180 \mathrm{rpm})$ at $20^{\circ} \mathrm{C}$ in the dark (Figure 3).

The differences in adaptation responses toward polar and nonpolar toxic compounds can be seen on the examples of PC and PG. Only a minority of bacterial strains contain PC in their membrane [10]. This phospholipid belongs to a bilayer forming group similarly to PG [12]. An increase in PC accumulation in membrane was observed after addition of nonpolar PCBs. Polar 3-CBA did not rapidly affect the amount of this phospholipid in the membrane. Only a slight increase of PC content was observed in both Pseudomonas species after 3-CBA addition. On the contrary, both pollutants caused the decrease of PE amount in all studied strains. As mentioned before, $\mathrm{PE}$ belongs to nonbilayer phospholipids. Presence of toxic pollutants leads to their accumulation in membrane and destabilizes the bilayer conformation. Cells counteract this effect by reducing the nonbilayer phospholipid fraction to increase membrane stability. This phenomenon was 
accompanied with an increase in membrane saturation and cis/trans isomerization to decrease membrane fluidity [28]. Nonpolar compounds are able to accumulate between the acyl chains of phospholipids and stimulate the hexagonal formation and increase $T_{M}$. As a result of such accumulation, increase of PG content in membrane can be expected. Our results obtained using the PCBs are in accordance with this assumption as can be seen in Figure 3. The presence of 3CBA caused the decrease of PG content. This can be explained by the ability of a polar compound to accumulate between the polar phospholipid parts (glycerol headgroups) and by a stimulation of micellar formation (interdigitated phase). PG has a larger headgroup volume; therefore, a decrease of the content of this membrane component increases membrane stability. The addition of PCBs evoked increase of PG and $\mathrm{PC}$ membrane incorporation and decrease of $\mathrm{PE}$ in bacterial cells. Both PC and PG are bilayer forming lipids, while PE is a nonbilayer lipid. These results are in agreement with the results obtained with different nonpolar toxic compounds [45].

3.2.1. Unique Status of Cardiolipin. Cardiolipin (diphosphatidylglycerol) is a unique phospholipid that plays an important role in cell membrane adaptation. Increase in its synthesis strongly enhances the adaptation ability of bacterial cell to the presence of organic solvents as well as to longterm starvation. This mechanism was observed mainly in Pseudomonas species [76].

$\mathrm{CL}$ is a minor component of bacterial membrane that can be found in many strains. Together with PG, it represents the most abundant anionic lipid component of bacterial membrane. These phospholipids are markedly present in a number of $\mathrm{G}^{+}$bacteria. It may trap protons in an acid structure and bind to a large number of unrelated proteins. The molecule consists of two phosphatidic acid residues linked by a glycerol. It contains four fatty acid chains per molecule and possesses one negative charge per headgroup (Figure 2(e)). $\mathrm{CL}$ is synthesized with enzyme cardiolipin synthase in cytoplasmic membrane. The synthase catalyses the transfer of phosphatidyl group between two phosphatidylglycerol molecules and is known as phospholipase D. This enzyme reacts with two PG molecules, one acting as phosphatidyl donor and the other as phosphatidyl acceptor. This enzyme does not have strict substrate specificity and may act in the reverse direction and decompose CL. Trace amount of CL occurs in bacterial cells during the exponential growth phase. Accumulation of CL increases at the beginning of stationary phase. It is the most stable of all membrane phospholipids and is essential for the survival upon long-time starvation. Only de novo synthesis of CL was described in bacteria [77]. Prokaryotes can change the amount of this lipid depending on their physiological status and growth conditions.

Increase of the amount of this phospholipid is a known adaptation mechanism in the stress environment. It may reflect a requirement for enhancement of the structural integrity of cytoplasmic membrane or for the support of stress related increases in energy transduction [78]. Another adaptation to long-term exposure to toxic solvent can be achieved with efflux pumps or increased biosynthesis and changes in phospholipids that support the adaptation and repair mechanisms [76]. CL stimulates changes in the physical properties of cytoplasmic membrane. Even small amounts of CL decrease the lateral interaction within the monolayer leaflet, which decreases the energy required to stretch the membrane and could favor the creation of membrane folds [79]. This is the reason why CL is concentrated in polar and septal regions of the cell. It is able to form nonlamellar structures that are required for membrane curvature and lead to the formation of clusters. The advantage of its unique conformation enables the nonlamellar structure to pack tightly forming microdomains which are stabilized by membrane proteins. Its ability to trap protons at $\mathrm{H}^{+}$uptake pathway of energy is due to its high $p K_{a}$ value ( $\left.>8\right)$ and may have implications for the distribution of the proton-motive force in energy-converting membranes [80, 81].

Recent studies confirmed that bacteria with CL synthase deficiency are more vulnerable to osmotic stress and organic solvents [82]. von Wallbrunn et al. [83] used a mutant bacterium that is not able to synthesize CL to find out whether the cis-trans isomerase is able to compensate CL in adaptation mechanisms. Their results demonstrated that the mutant was not able to grow, which proved that cis-trans isomerase was not fully able to replace adaptation effect of CL.

3.3. Efflux Pumps and Solvent Transport. Bacteria have developed various systems to eliminate toxic compounds naturally present in the environment. This led to the occurrence of multidrug resistance that is a dangerous property of some important pathogens [84]. Such elimination takes place by an uncontrolled efflux and accelerates active extrusion of structurally unrelated compounds from cytoplasm or cytoplasmic membrane to the external space. Toxic pollutants may represent substrates for the efflux system. Several studies indicated the importance of physical properties of compounds (hydrophobicity or molecule charge) for the determination of specificities of this mechanism [8587]. The efflux system transporters for organic compounds identified in multidrug resistant $\mathrm{G}^{-}$bacteria belong to the RND family (resistance nodulation cell division) of pumps that are encoded chromosomally [88]. This system consists of complex transporters, which export toxic compounds through the cell membranes in a single energy coupled step. It requires a cytoplasmic membrane export system, which acts as an energy-dependent extrusion pump, a membrane fusion protein, and an outer membrane factor $[39,89]$. It was found that primary multidrug efflux system AcrAB-TolC facilitated the efflux of hydroxyl-PCBs out of the cells [90]. These multidrug resistant pumps may affect the accumulation and degradation of PCBs by bacteria. Moreover, adapted bacteria of Pseudomonas sp. accumulated lower amount of trichlorobenzene in cells than nonadapted strains [76]. Similar results were published with toluene by Segura et al. [91]. The ability of E. coli to eliminate PCBs and hydroxylPCBs was studied by Geng et al. [90]. The correlation between the multidrug resistance and the efflux of toxic pollutant by Pseudomonas aeruginosa was studied in detail by Muller [92]. 
Rojas et al. [89] described that some of the efflux pumps act on a restricted range of substrates. An example of such pump is TtfDEF pump from Pseudomonas putida DOT-T1E, which extrudes only toluene and styrene. Other pumps have a broad range of structurally diverse compounds. MexABOprM from $P$. aeruginosa can extrude hexane, $\mathrm{p}$-xylene, and PCBs as well as antibiotics [93].

\subsection{Proteome}

3.4.1. Effect of Pollutants on Membrane Proteins. As a result of the induced change in the membrane lipids, the membrane proteins are affected as well. Adaptation to some organic solvents results in a higher ratio of proteins to phospholipids. This decreases membrane fluidity because of the hindrance of lipid motion with proteins [94]. Cytoplasmic membrane contains mainly solute transport enzymes and proteins involved in electron transport chains. Their activity is changed depending on physicochemical membrane properties (fluidity and bilayer stability) and membrane thickness [9]. Sikkema et al. [21] described the decrease of cytochrome $\mathrm{c}$ activity in the presence of polycyclic aromatic hydrocarbons (PAHs). The type of phospholipid headgroup has a pronounced influence on the enzyme activity [95], although the fatty acid composition (lipid ordering) does not affect membrane enzymes. The activity of $\mathrm{Ca}^{2+}$-ATPase can be an example. High content of PE increases activity of this enzyme. Some membrane proteins depend on specific boundary phospholipids [45]. Correct orientation and arrangement of specific membrane proteins fully depend on these phospholipids.

3.4.2. Production of Special Proteins. Another known response of bacterial cells is the production and overexpression of stress proteins [96-101]. Induction of stress proteins in E. coli with aromatic compounds, such as 2,4-dinitrophenol (DNP) and benzoate, has been reported [102, 103]. Other stress proteins DnaK and GroEL are induced by 2,4dichlorophenoxyacetic acid in Burkholderia sp. YK-2 [104] and by 4-chlorobiphenyl and biphenyl in B. xenovorans LB400 [97]. Expression regulation of the stress proteins was reviewed by Hecker and Völker [105]. The role of alternative sigma factor $\sigma^{\mathrm{B}}$ in this adaptation was emphasized. This factor controls the production of bmrUR operon in $\mathrm{G}^{+}$ Bacillus subtilis necessary for the production of multidrug efflux proteins [33]. Toxic environment not only acts on the envelope, but usually affects the cell proteome as well. Damaged proteins can be replaced with the newly synthesized; however, this method is not efficient under nutrient limitations. Therefore, the proteome repair is required to maintain cell vitality. Visick and Clarke [106] described three major mechanisms, which operate in bacteria after a proteome damage induced by environment. First mechanisms include the chaperones, which assist in proper de novo folding of proteins and also provide an important means of restoring activity to damaged proteins. Second mechanism describes the existence of enzymatic repair systems that directly reverse certain forms of protein damage, including proline isomerization, methionine oxidation, and the formation of isoaspartyl residues. Third mechanism concerns proteolysis of abnormal proteins, which cannot be repaired.

Martínez et al. [98] described the effect of 4chlorobenzoic and 2-chlorobenzoic acids on B. xenovorans LB400. No effect on membrane lipids was observed. The primary adaptation was revealed as an overexpression of 11 proteins (the highest being the overproduction of catechol1,2-dioxygenase, belonging to 3-oxoadipate chlorobenzoate degradation pathway). Stress proteins, metabolic proteins, and elongation factors were stimulated as well. Similar induction of metabolic proteins in response to the aromatic compounds was described by Santos et al. [107] and Segura et al. [108]. Ethanol induced production of heat-shock proteins was observed also in E. coli [109]. The production of shock proteins belongs to nonspecific general stress responses.

3.5. Cell Wall. Cell envelope of all microorganisms consists of cell wall and cytoplasmic membrane. These covering components protect cell nucleus against the outside effects and help in communication with other cells. Most of the adaptation mechanisms discussed in this review are connected with cytoplasmic membrane as highly selective barrier. Moreover, the first line of cell protection is based on the alteration of the membrane composition that leads to lower fluidity and permeability toward toxic compounds. However, cell wall plays also a significant role in cell interior protection. Toxic compounds must firstly penetrate cell wall to reach other cell components. The cell wall of various bacterial strains serves as molecule sieve that prevents the transport of compounds with molecular weight higher than 600-1000 Da [19]. This surface structure is quite dissimilar in $\mathrm{G}^{+}$and $\mathrm{G}^{-}$ bacteria. $\mathrm{G}^{+}$bacterial strains have thick murein containing cell wall convoluted with teichoic acids. The role of murein layer in the exclusion of toxic compounds from cell is improbable because of its structure and properties. Mycolata (Rhodococcus, Mycobacterium, Nocardia, Corynebacterium, Gordonia, Dietzia, Skermania, and Tsukamurella) represent a specific taxon of $\mathrm{G}^{+}$bacteria that are extremely resistant to drugs and toxic hydrophobic compounds. The cell wall of the taxon is unique in its composition and organization compared to other $\mathrm{G}^{+}$bacteria. The dominant abundance has arabinogalactan polysaccharide, which is linked with large 2-alkyl 3-hydroxy branched-chain fatty acids called mycolic acids. This covalently assembled complex is responsible for the cell surface hydrophobicity and impermeability [110-112]. The cell hydrophobic character helps mycolata to uptake the hydrophobic substrate from the environment without the production of surfactant and enables the use of such bacteria in bioremediation technologies [34-36].

Contrarily, $\mathrm{G}^{-}$bacteria have a very thin murein layer that is linked from the outside part with the outer layer. The predominant component of this addition layer is lipopolysaccharide (LPS). LPS is composed of polysaccharide chains with six to seven saturated fatty acids bond in glucosamine disaccharide structure. Thanks to these tightly packed saturated fatty acids, LPS has a very low permeability to hydrophobic 
compounds and, thus, can act as cell protection [39, 113]. LPS polysaccharide chain plays a role in cell resistance as well. The studies with $E$. coli mutants unable to synthesize these polysaccharides showed high sensitivity of the mutants toward hydrophobic antibiotics, detergents, and other drugs [45].

Moreover, changes in LPS composition led to higher o-xylene resistance of Pseudomonas putida Idaho. LPS molecules with high molecular weight were replaced by lower weight bands to adapt to o-xylene [114]. This notion of a protective function of LPS can be supported by a lower sensitivity of $\mathrm{G}^{-}$bacteria toward various organic contaminants such as PCBs, toluene, benzene, or biphenyl $[26,28,115]$. The amount and type of LPS molecules present in bacterial cell wall have a crucial effect on the bacterial surface properties as hydrophobicity and adhesion with outer surfaces and substrates [116]. The decrease of cell hydrophobicity generally leads to lower cell availability toward lipophilic contaminants and diminished permeability [84].

However, some of the adapted microorganisms are able to use the hydrophobic solvents as energy source [117]. Under the circumstances, uptake of such substrates is provided with the release of LPS molecules and enclosing of hydrophobic substrates with hydrocarbon droplets [118]. $\mathrm{G}^{+}$ bacterium Mycobacterium frederiksbergense showed increase in cell hydrophobicity in the presence of anthracene instead of glucose. Anthracene served as a carbon source for the strain. Bacterium increased the cell surface availability for the metabolic process [31]. Some microorganisms that are capable of utilization of hydrophobic contaminants produce biosurfactants and extracellular mucor to increase bioavailability of such unique carbon sources [119].

Cell survival in inhospitable environment can be supported by the addition of divalent ions $\left(\mathrm{Mg}^{2+}\right.$ and $\left.\mathrm{Ca}^{2+}\right)$. It is supposed that these divalent ions can diminish the charge repulsion of adjacent polyanionic LPS molecules with their electrostatic bond. As a consequence, firm ordering of LPS molecules influences membrane stability and the entry of toxic organic compounds. Higher toluene resistance of Pseudomonas species was observed after the supplementation of cultivation media with divalent ions [45]. Toluene adaptation correlated with lowered surface hydrophobicity [39]. Higher surface hydrophobicity was observed in the presence of toxic water-soluble arsenical compounds. This effect increased the tolerance of Euglena mutabilis and Euglena gracilis to hydrophilic toxic compound but not to hydrophobic ones [120]. The removal of LPS molecules can lead to the loss of the resistance to toxic contaminants [113, 121].

Although the penetration of external compounds is diminished by outer membrane, large number of small molecules can move through this cell structure through protein canals. Some of the canals forming proteins are highly specific with specific binding sites facilitating the transport of certain molecules. Other proteins called porins allow nonspecific diffusion, necessary for the nutrient and water influx $[87,115]$. Porins are water filled protein canals embedded in the outer membrane. Bacterial resistance toward rather hydrophilic antibiotics is related to the porin mutations [122]. OmpF porin is supposed to be a good transporter for organic solvents [123]. Contrast effect was observed with porin OmpL. Its absence leads to the solvent hypersensitivity, because of its stabilization effect to cell wall integrity [76]. The adaptation to solvents does not only enhance the resistance to other solvents but also enhances the resistance to heavy metals and antibiotics [124].

\section{Other Adaptation Responses}

Another mechanism of microorganism adaptation is the accumulation of special compatible solutes like trehalose, betaine, rhamnolipid biosurfactants, and proline. These solutes were found in cell of stress survived microorganisms because of their ability to protect cell against low temperatures with their effect on lipid ordering and membrane fluidity [125-127]. The solvent accumulation between the phospholipid headgroups increases the membrane fluidity and permeability. As a result, proton leakage can be observed, which leads to the loss of proton-motive force. Bacteria can stimulate the activity of $\mathrm{H}^{+}$ATPase in the presence of high concentration of solvents to decrease the loss of protons [128].

The adaptation of outer membrane is also connected with the formation of outer membrane vesicles [129]. Membrane vesicles play an important role in interspecies communication [130] and the delivery of proteins, toxins, and DNA. Kobayashi et al. [131] discussed the possibility of toluenecontaining membrane vesicles as an adaptation mechanism to transport toxic compounds away from the cells. In addition, an important function of membrane vesicles release is their involvement in biofilm formation [132]. Bacteria growing in biofilms are known to be significantly more tolerant to antibiotics, biocides, and other forms of environmental stress $[132,133]$.

Changes in cell morphology in the presence of toxic compounds were observed in $\mathrm{G}^{-}[134]$ as well as in $\mathrm{G}^{+}$bacteria [30]. General responses of $\mathrm{G}^{-}$bacteria to environmental stress were attributed to increase in cell size. $\mathrm{G}^{+}$bacteria showed filamentous growth, increased cell volume, formation of endospores [32], and production of unusual extracellular capsule [135].

Another efficient way of how to cope with toxic compounds is to decrease their toxic effect with their degradation or modification. The degradation enzymes are bond to the inner part of cytoplasmic membrane. The ability of hydrophobic compounds to accumulate in cytoplasmic membrane is minimized with hydroxylation of the compound. The usual degradation pathway begins with the incorporation of hydroxyl group into the pollutant structure $[1,95,136,137]$. However, increase in pollutant's polarity leads to its higher water solubility and higher availability to the microorganism itself. This situation usually leads to higher toxicity of the environment. Therefore, the microorganisms able to modify toxic compounds try to cooperate with other organisms to achieve complete mineralization of contaminants into $\mathrm{CO}_{2}$ and water or at least transform the initial compounds into nontoxic intermediate.

Some molecules present in the nature can help bacteria to survive in the contaminated environment. The mechanisms 
of these compounds have not been described in detail yet. However, we described that some of these compounds are able to diminish bacterial adaptation mechanisms relating to fatty acids composition [138]. Natural matrices rich in terpene content belong to this group. Many studies described the stimulation effect of ivy leaves, pine needles [139], eucalyptus leaves, tangerine, and orange peel [140-142] to the biodegradation of hydrophobic pollutants. Potential use of synthetic terpenes and natural matrices containing these compounds in the stimulation of bacterial adaptation was studied in our previous works [28, 138, 143]. Our results clearly indicated the positive effect of natural terpene containing matrices, ivy leaves, and pine needles on bacterial survival in the presence of polychlorinated biphenyls (PCBs). Ivy leaves decreased the adaptation responses of Pseudomonas stutzeri and Burkholderia xenovorans LB400 toward PCBs and increased the biomass growth. Contrast effect was observed in the presence of synthetic terpenes (carvone and limonene) which correspond with other papers [144-148]. Although the positive effects of natural terpenes on bacterial adaptation and survival in the PCB contaminated media have been observed, it is necessary to study the mechanisms of such effect with other toxic contaminants in future works.

\section{Conclusions and Future Prospects}

A number of responses have been observed in bacteria that counteract the effect of organic pollutants. Rigidification of the cell membrane is a consequence of cell adaptation. The alterations in cytoplasmic membrane maintain particular ratio between bilayer and nonbilayer (hexagonal) phospholipids (prevention against the environmentally induced formation of interdigitated structure) and keep the optimal phospholipid ordering to stabilize membrane fluidity. Another mechanism to protect bacterial cell is the efflux of toxic compounds from the membrane bilayer or its degradation. Toxic compounds affect not only cytoplasmic lipids but also cell proteins. This resulted in the development of special protein repair mechanisms by the bacteria. Changes in cell metabolism reflect the degree of pollutant toxicity. Study of these mechanisms is the first step in selection of proper bacterial strains for bioremediation application. Successful environment decontamination requires bacterial strains that are able to degrade particular (one or more) contaminants. Moreover, such strains have to be able to survive and adapt to environmental pollution.

The successful decontamination process use of adapted strains and optimization of bioremediation conditions have been currently extensively studied. The degradation studies in artificial precisely defined matrices (liquid medium, enriched soil, or sediment) and in naturally contaminated matrices under laboratory conditions (microcosms) should be subsequently applied under natural conditions in smaller range (mesocosms).

Another possibility is genetic modification of excellent bacterial degraders to survive under adverse environmental conditions. That allows the degraders to apply their degradation ability (expression of the relevant enzymes) in decontamination process without inhibition of the physiological processes in bacterial cells.

\section{Conflict of Interests}

The authors declare that there is no conflict of interests regarding the publication of this paper.

\section{Acknowledgments}

This work was supported by the Scientific Grant Agency of the Ministry of Education, Science, and Sport of Slovak Republic VEGA no. 1/0734/12 and by the Slovak Research and Development Agency under the Contract no. APVV-065612.

\section{References}

[1] J. Tř́íska, G. Kuncová, M. Macková et al., "Isolation and identification of intermediates from biodegradation of low chlorinated biphenyls (DELOR-103)," Chemosphere, vol. 54, no. 6, pp. 725733, 2004.

[2] R. Tandlich, B. Vrana, S. Payne, K. Dercová, and S. Balaz, "Biodegradation mechanism of biphenyl by a strain of Pseudomonas stutzeri," Journal of Environmental Science and Health A: Toxic/Hazardous Substances and Environmental Engineering, vol. 46, no. 4, pp. 337-344, 2011.

[3] H. J. Heipieper, F. J. Weber, J. Sikkema, H. Keweloh, and J. A. M. de Bont, "Mechanisms of resistance of whole cells to toxic organic solvents," Trends in Biotechnology, vol. 12, no. 10, pp. 409-415, 1994.

[4] J. Šajbidor, "Effect of some environmental factors on the content and composition of microbial membrane lipids," Critical Reviews in Biotechnology, vol. 17, no. 2, pp. 87-103, 1997.

[5] M. Čertík and E. Breierová, "Adaptation responses of yeasts to environmental stress," Chemical Letters, vol. 96, pp. 154-160, 2002.

[6] T. J. Denich, L. A. Beaudette, H. Lee, and J. T. Trevors, "Effect of selected environmental and physico-chemical factors on bacterial cytoplasmic membranes," Journal of Microbiological Methods, vol. 52, no. 2, pp. 149-182, 2003.

[7] M. Čertík, K. Dercová, Z. Sejáková, M. Find’ová, and T. Jakubík, "Effect of polyaromatic hydrocarbons (PAHs) on the membrane lipids of bacterial cell," Biologia, vol. 58, no. 6, pp. 1111-1117, 2003.

[8] F. J. Weber, S. Isken, and J. A. M. De Bont, "Cis/trans isomerization of fatty adds as a defence mechanism of Pseudomonas putida strains to toxic concentrations of toluene," Microbiology, vol. 140, no. 8, pp. 2013-2017, 1994.

[9] I. Barák and K. Muchová, "The role of lipid domains in bacterial cell processes," International Journal of Molecular Sciences, vol. 14, no. 2, pp. 4050-4065, 2013.

[10] D. E. Vance and J. Vance, Biochemistry of Lipids, Lipoproteins and Membranes, Elsevier Science BV, 1996.

[11] T. Kobayashi, A. Ohta, and I. Shibuya, "Membrane phospholipid synthesis in Escherichia coli: alteration by glycerol and physiological consequences in a pss mutant," Journal of Biochemistry, vol. 99, no. 5, pp. 1393-1400, 1986. 
[12] W. Dowhan, M. Bogdanov, and E. Mileykovskaya, "Functional roles of lipids in membranes," in Biochemistry of Lipids, Lipoproteins and Membranes, D. E. Vance and J. E. Vance, Eds., Elsevier, Amsterdam, The Netherlands, 2008.

[13] J. M. Berg, J. L. Tymoczko, and L. Stryer, Biochemistry, WH Freeman and Company, New York, NY, USA, 2006.

[14] P. De Weer, "A century of thinking about cell membranes," Annual Review of Physiology, vol. 62, pp. 919-926, 2000.

[15] B. A. Lewis and D. M. Engelman, "Lipid bilayer thickness varies linearly with acyl chain length in fluid phosphatidylcholine vesicles," Journal of Molecular Biology, vol. 166, no. 2, pp. 211217, 1983.

[16] P. J. L. Werten, H. W. Rémigy, B. L. de Groot et al., "Progress in the analysis of membrane protein structure and function," The FEBS Letters, vol. 529, no. 1, pp. 65-72, 2002.

[17] K. Simons and W. L. C. Vaz, "Model systems, lipid rafts, and cell membranes," Annual Review of Biophysics and Biomolecular Structure, vol. 33, pp. 269-295, 2004.

[18] N. Beales, "Adaptation of microorganisms to cold temperatures, weak acid preservatives, low $\mathrm{pH}$, and osmotic stress: a review," Comprehensive Reviews in Food Science, vol. 3, pp. 1-20, 2004.

[19] J. Sikkema, J. A. M. de Bont, and B. Poolman, "Mechanisms of membrane toxicity of hydrocarbons," Microbiological Reviews, vol. 59, no. 2, pp. 201-222, 1995.

[20] H.-. Heipieper, R. Diefenbach, and H. Keweloh, "Conversion of cis unsaturated fatty acids to trans, a possible mechanism for the protection of phenol-degrading Pseudomonas putida P8 from substrate toxicity," Applied and Environmental Microbiology, vol. 58, no. 6, pp. 1847-1852, 1992.

[21] J. Sikkema, J. A. M. de Bont, and B. Poolman, "Interactions of cyclic hydrocarbons with biological membranes," Journal of Biological Chemistry, vol. 269, no. 11, pp. 8022-8028, 1994.

[22] P. Jurkiewicz, A. Olzyńska, L. Cwiklik et al., "Biophysics of lipid bilayers containing oxidatively modified phospholipids: insights from fluorescence and EPR experiments and from MD simulations," Biochimica et Biophysica Acta-Biomembranes, vol. 1818, no. 10, pp. 2388-2402, 2012.

[23] S. K. B. Ghorbal, A. Chatti, M. M. Sethom et al., "Changes in membrane fatty acid composition of Pseudomonas aeruginosa in response to UV-C radiations," Current Microbiology, vol. 67, no. 1, pp. 112-117, 2013.

[24] R. Diefenbach, H.J. Heipieper, and H. Keweloh, “The conversion of cis into trans unsaturated fatty acids in Pseudomonas putita P8: evidence for a role in the regulation of membrane fluidity," Applied Microbiology and Biotechnology, vol. 38, no. 3, pp. 382387, 1992.

[25] H. J. Heipieper, F. Meinhardt, and A. Segura, "The cis-trans isomerase of unsaturated fatty acids in Pseudomonas and Vibrio: biochemistry, molecular biology and physiological function of a unique stress adaptive mechanism," FEMS Microbiology Letters, vol. 229, no. 1, pp. 1-7, 2003.

[26] A. Mrozik, S. Łabuzek, and Z. Piotrowska-Seget, "Changes in fatty acid composition in Pseudomonas putida and Pseudomonas stutzeri during naphthalene degradation," Microbiological Research, vol. 160, no. 2, pp. 149-157, 2005.

[27] M. Pepi, H. J. Heipieper, J. Fischer, M. Ruta, M. Volterrani, and S. E. Focardi, "Membrane fatty acids adaptive profile in the simultaneous presence of arsenic and toluene in Bacillus sp. ORAs2 and Pseudomonas sp. ORAs5 strains," Extremophiles, vol. 12, no. 3, pp. 343-349, 2008.
[28] S. Zorádová, H. Dudášová, L. Lukáčová, K. Dercová, and M. Čertík, "The effect of poly-chlorinated biphenyls (PCBs) on the membrane lipids of Pseudomonas stutzeri," International Biodeterioration and Biodegradation, vol. 65, pp. 1019-1023, 2011.

[29] M. M. Donato, A. S. Jurado, M. C. Antunes-Madeira, and V. M. C. Madeira, "Effects of a lipophilic environmental pollutant (DDT) on the phospholipid and fatty acid contents of Bacillus stearothermophilus," Archives of Environmental Contamination and Toxicology, vol. 33, no. 4, pp. 341-349, 1997.

[30] L. E. Nielsen, D. R. Kadavy, S. Rajagopal, R. Drijber, and K. W. Nickerson, "Survey of extreme solvent tolerance in grampositive cocci: Membrane fatty acid changes in Staphylococcus haemolyticus grown in toluene," Applied and Environmental Microbiology, vol. 71, no. 9, pp. 5171-5176, 2005.

[31] S. Yamashita, M. Satoi, Y. Iwasa et al., "Utilization of hydrophobic bacterium Rhodococcus opacus B-4 as whole-cell catalyst in anhydrous organic solvents," Applied Microbiology and Biotechnology, vol. 74, no. 4, pp. 761-767, 2007.

[32] S. Torres, S. L. M. Pera, A. Pandey, and G. R. Castro, "Study on the effects of organic solvent stress on Bacillus lichenifomis S-86," in Current Topics on Bioprocesses in Food Industry, L. V. Rao, A. Pandey, C. Larroche, and C. G. Dussap, Eds., pp. 1-13, Asiatech Publishers, New Delhi, India, 2009.

[33] S. Torres, A. Pandey, and G. R. Castro, "Organic solvent adaptation of Gram positive bacteria: applications and biotechnological potentials," Biotechnology Advances, vol. 29, no. 4, pp. 442-452, 2011.

[34] C. C. C. R. de Carvalho, A. A. R. L. da Cruz, M. Pons et al., "Mycobacterium sp., Rhodococcus erythropolis, and Pseudomonas putida behavior in the presence of organic solvents," Microscopy Research and Technique, vol. 64, no. 3, pp. 215-222, 2004.

[35] C. C. C. R. de Carvalho, V. Fatal, S. S. Alves, and M. M. R. Da Fonseca, "Adaptation of Rhodococcus erythropolis cells to high concentrations of toluene," Applied Microbiology and Biotechnology, vol. 76, no. 6, pp. 1423-1430, 2007.

[36] P. Fernandes, M. P. C. Marques, F. Carvalho, and C. C. C. R. de Carvalho, "Organic-solvent tolerant gram-positive bacteria: applications and mechanisms of tolerance," in Organic Solvents: Properties, Toxocoty, and Industrial Effects, R. E. Carter, Ed., pp. 89-104, Nova Science, New York, NY, USA, 2011.

[37] K. Trautwein, S. Kühner, L. Wöhlbrand et al., "Solvent stress response of the denitrifying bacterium "Aromatoleum aromaticum" strain EbN1," Applied and Environmental Microbiology, vol. 74, no. 8, pp. 2267-2274, 2008.

[38] I. Duldhardt, J. Gaebel, L. Chrzanowski et al., "Adaptation of anaerobically grown Thauera aromatica, Geobacter sulfurreducens and Desulfococcus multivorans to organic solvents on the level of membrane fatty acid composition," Microbial Biotechnology, vol. 3, no. 2, pp. 201-209, 2010.

[39] A. Segura, E. Duque, G. Mosqueda, J. L. Ramos, and F. Junker, "Multiple responses of Gram-negative bacteria to organic solvents," Environmental Microbiology, vol. 1, no. 3, pp. 191-198, 1999.

[40] K. Dercová, M. Čertík, A. Mal'ová, and Z. Sejáková, "Effect of chlorophenols on the membrane lipids of bacterial cells," International Biodeterioration and Biodegradation, vol. 54, pp. 251-254, 2004.

[41] H. Y. Oh, J. O. Lee, and O. B. Kim, "Increase of organic solvent tolerance of Escherichia coli by the deletion of two regulator genes, fadR and marR," Applied Microbiology and Biotechnology, vol. 96, no. 6, pp. 1619-1627, 2012. 
[42] A. Mrozik, S. Łabuzek, and Z. Piotrowska-Seget, "Changes in whole cell-derived fatty acids induced by naphthalene in bacteria from genus Pseudomonas," Microbiological Research, vol. 159, no. 1, pp. 87-95, 2004.

[43] H. Keweloh, R. Diefenbach, and H. J. Rehm, "Increase of phenol tolerance of Escherichia coli by alterations of the fatty acid composition of the membrane lipids," Archives of Microbiology, vol. 157, no. 1, pp. 49-53, 1991.

[44] J. A. Gutiérrez, P. Nichols, and L. Couperwhite, "Changes in whole cell-derived fatty acids induced by benzene and occurrence of the unusual 16:1w6c in Rhodococcus sp. 33," FEMS Microbiology Letters, vol. 176, no. 1, pp. 213-218, 1999.

[45] F. J. Weber and J. A. M. de Bont, "Adaptation mechanisms of microorganisms to the toxic effects of organic solvents on membranes," Biochimica et Biophysica Acta-Reviews on Biomembranes, vol. 1286, no. 3, pp. 225-245, 1996.

[46] J. R. Hazel and E. E. Williams, "The role of alternations in membrane lipid composition in enabling physiological adaptation of organisms to their physical environment," Progress in Lipid Research, vol. 29, no. 3, pp. 167-227, 1990.

[47] J. E. Cronan Jr., "Phospholipid modifications in bacteria," Current Opinion in Microbiology, vol. 5, no. 2, pp. 202-205, 2002.

[48] N. Kabelitz, P. M. Santos, and H. J. Heipieper, "Effect of aliphatic alcohols on growth and degree of saturation of membrane lipids in Acinetobacter calcoaceticus," FEMS Microbiology Letters, vol. 220, no. 2, pp. 223-227, 2003.

[49] H. J. Heipieper and J. A. M. de Bont, "Adaptation of Pseudomonas putida S12 to ethanol and toluene at the level of fatty acid composition of membranes," Applied and Environmental Microbiology, vol. 60, no. 12, pp. 4440-4444, 1994.

[50] R. Y.-Y. Chiou, R. D. Phillips, P. Zhao, M. P. Doyle, and L. R. Beuchat, "Ethanol-mediated variations in cellular fatty acid composition and protein profiles of two genotypically different strains of Escherichia coli O157:H7," Applied and Environmental Microbiology, vol. 70, no. 4, pp. 2204-2210, 2004.

[51] H. Keweloh and H. J. Heipieper, "Trans unsaturated fatty acids in bacteria," Lipids, vol. 31, no. 2, pp. 129-137, 1996.

[52] H. J. Heipieper, G. Neumann, N. Kabelitz, M. Kastner, and H. H. Richnow, "Carbon isotope fractionation during cistrans isomerization of unsaturated fatty acids in Pseudomonas putida," Applied Microbiology and Biotechnology, vol. 66, no. 3, pp. 285-290, 2004.

[53] H. J. Heipieper, G. Meulenbeld, Q. van Oirschot, and J. A. M. de Bont, "Effect of environmental factors on the trans/cis ratio of unsaturated fatty acids in Pseudomonas putida S12," Applied and Environmental Microbiology, vol. 62, no. 8, pp. 2773-2777, 1996.

[54] R. Holtwick, H. Keweloh, and F. Meinhardt, "Cis/trans isomerase of unsaturated fatty acids of Pseudomonas putida P8: evidence for a heme protein of the cytochrome c type," Applied and Environmental Microbiology, vol. 65, no. 6, pp. 2644-2649, 1999.

[55] A. Von Wallbrunn, H. H. Richnow, G. Neumann, F. Meinhardt, and H. J. Heipieper, "Mechanism of cis-trans isomerization of unsaturated fatty acids in Pseudomonas putida," Journal of Bacteriology, vol. 185, no. 5, pp. 1730-1733, 2003.

[56] H. J. Heipieper, P. de Waard, P. van der Meer et al., "Regiospecific effect of 1-octanol on cis-trans isomerization of unsaturated fatty acids in the solvent-tolerant strain pseudomonas putida S12," Applied Microbiology and Biotechnology, vol. 57, no. 4, pp. 541-547, 2001.

[57] V. Pedrotta and B. Witholt, "Isolation and characterization of the cis-trans-unsaturated fatty acid isomerase of Pseudomonas oleovorans gpo12," Journal of Bacteriology, vol. 181, no. 10, pp. 3256-3261, 1999.

[58] F. Junker and J. L. Ramos, "Involvement of the cis/trans isomerase Cti in solvent resistance of Pseudomonas putida DOT-T1E," Journal of Bacteriology, vol. 181, no. 18, pp. 5693$5700,1999$.

[59] N. Morita, A. Shibahara, K. Yamamoto, K. Shinkai, G. Kajimoto, and H. Okuyama, "Evidence for cis-trans isomerization of a double bond in the fatty acids of the psychrophilic bacterium Vibrio sp. strain ABE-1," Journal of Bacteriology, vol. 175, no. 3, pp. 916-918, 1993.

[60] R. Diefenbach and H. Keweloh, "Synthesis of trans unsaturated fatty acids in Pseudomonas putida P8 by direct isomerization of the double bond of lipids," Archives of Microbiology, vol. 162, no. 1-2, pp. 120-125, 1994.

[61] I. S. Kim, H. Lee, and J. T. Trevors, "Effects of 2,2I,5,5/tetrachlorobiphenyl and biphenyl on cell membranes of Ralstonia eutropha H850," FEMS Microbiology Letters, vol. 200, no. 1, pp. 17-24, 2001.

[62] A. Mrozik, M. Cycoń, and Z. Piotrowska-Seget, "Changes of FAME profiles as a marker of phenol degradation in different soils inoculated with Pseudomonas sp. CF600," International Biodeterioration and Biodegradation, vol. 64, no. 1, pp. 86-96, 2010.

[63] L. Shabala and T. Ross, "Cyclopropane fatty acids improve Escherichia coli survival in acidified minimal media by reducing membrane permeability to $\mathrm{H}^{+}$and enhanced ability to extrude $\mathrm{H}^{+}$," Research in Microbiology, vol. 159, no. 6, pp. 458-461, 2008.

[64] N. Loffhagen, C. Härtig, and W. Babel, "Suitability of the trans/cis ratio of unsaturated fatty acids in Pseudomonas putida NCTC 10936 as an indicator of the acute toxicity of chemicals," Ecotoxicology and Environmental Safety, vol. 50, no. 1, pp. 65-71, 2001.

[65] N. E. Chihib, Y. Tierny, P. Mary, and J. P. Hornez, "Adaptational changes in cellular fatty acid branching and unsaturation of Aeromonas species as a response to growth temperature and salinity," International Journal of Food Microbiology, vol. 102, no. 1, pp. 113-119, 2005.

[66] A. Kaur, A. Chaudhary, R. Choudhary, and R. Kaushik, "Phospholipid fatty acid-a bioindicator of environment monitoring and assessment in soil ecosystem," Current Science, vol. 89, no. 7, pp. 1103-1112, 2005.

[67] A. Mrozik, Z. Piotrowska-Seget, and S. Łabuzek, "FAMEs profiles of phenol-degrading Pseudomonas stutzeri introduced into soil," International Biodeterioration and Biodegradation, vol. 62, no. 3, pp. 319-324, 2008.

[68] J. L. Ramos, E. Duque, M. Gallegos et al., "Mechanisms of solvent tolerance in gram-negative bacteria," Annual Review of Microbiology, vol. 56, pp. 743-768, 2002.

[69] B. Perly, I. C. P. Smith, and H. C. Jarrell, "Effects of the replacement of a double bond by a cyclopropane ring in phosphatidylethanolamines: A $2 \mathrm{H} \mathrm{NMR}$ study of phase transitions and molecular organization," Biochemistry, vol. 24, no. 4, pp. 1055-1063, 1985.

[70] D. W. Grogan and J. E. Cronan Jr., "Cyclopropane ring formation in membrane lipids of bacteria," Microbiology and Molecular Biology Reviews, vol. 61, no. 4, pp. 429-441, 1997.

[71] I. V. Tsitko, G. M. Zaitsev, A. G. Lobanok, and M. S. SalkinojaSalonen, "Effect of aromatic compounds on cellular fatty acid composition of Rhodococcus opacus," Applied and Environmental Microbiology, vol. 65, no. 2, pp. 853-855, 1999. 
[72] T. Kaneda, "Iso- and anteiso-fatty acids in bacteria: biosynthesis, function, and taxonomic significance," Microbiological Reviews, vol. 55, no. 2, pp. 288-302, 1991.

[73] M. Unell, N. Kabelitz, J. K. Jansson, and H. J. Heipieper, "Adaptation of the psychrotroph Arthrobacter chlorophenolicus A6 to growth temperature and the presence of phenols by changes in the anteiso/iso ratio of branched fatty acids," FEMS Microbiology Letters, vol. 266, no. 2, pp. 138-143, 2007.

[74] I. Duldhardt, I. Nijenhuis, F. Schauer, and H. J. Heipieper, "Anaerobically grown Thauera aromatica, Desulfococcus multivorans, Geobacter sulfurreducens are more sensitive towards organic solvents than aerobic bacteria," Applied Microbiology and Biotechnology, vol. 77, no. 3, pp. 705-711, 2007.

[75] T. Romantsov, Z. Guan, and J. M. Wood, "Cardiolipin and the osmotic stress responses of bacteria," Biochimica et Biophysica Acta, vol. 1788, no. 10, pp. 2092-2100, 2009.

[76] J. L. Ramos, E. Duque, J. Rodríguez-Herva et al., "Mechanisms for solvent tolerance in bacteria," Journal of Biological Chemistry, vol. 272, no. 7, pp. 3887-3890, 1997.

[77] M. Schlame, "Cardiolipin synthesis for the assembly of bacterial and mitochondrial membranes," Journal of Lipid Research, vol. 49, no. 8, pp. 1607-1620, 2008.

[78] F. Prossnigg, A. Hickel, G. Pabst, and K. Lohner, "Packing behaviour of two predominant anionic phospholipids of bacterial cytoplasmic membranes," Biophysical Chemistry, vol. 150, no. 1-3, pp. 129-135, 2010.

[79] S. Nichols-Smith, S. Teh, and T. L. Kuhl, "Thermodynamic and mechanical properties of model mitochondrial membranes," Biochimica et Biophysica Acta: Biomembranes, vol. 1663, no. 12, pp. 82-88, 2004.

[80] T. H. Haines and N. A. Dencher, "Cardiolipin: a proton trap for oxidative phosphorylation," The FEBS Letters, vol. 528, no. 1-3, pp. 35-39, 2002.

[81] H. Palsdottir and C. Hunte, "Lipids in membrane protein structures," Biochimica et Biophysica Acta-Biomembranes, vol. 1666, no. 1-2, pp. 2-18, 2004.

[82] P. Bernal, J. Muñoz-Rojas, A. Hurtado, J. L. Ramos, and A. Segura, "A Pseudomonas putida cardiolipin synthesis mutant exhibits increased sensitivity to drugs related to transport functionality, Environmental Microbiology, vol. 9, no. 5, pp. 1135-1145, 2007.

[83] A. von Wallbrunn, H. Heipieper, and F. Meinhardt, "Cis/trans isomerisation of unsaturated fatty acids in a cardiolipin synthase knock-out mutant of Pseudomonas putida P8," Applied Microbiology and Biotechnology, vol. 60, no. 1-2, pp. 179-185, 2003.

[84] P. Fernandes, B. S. Ferreira, and J. M. S. Cabral, "Solvent tolerance in bacteria: role of efflux pumps and cross-resistance with antibiotics," International Journal of Antimicrobial Agents, vol. 22, no. 3, pp. 211-216, 2003.

[85] I. T. Paulsen, M. H. Brown, and R. A. Skurray, "Protondependent multidrug efflux systems," Microbiological Reviews, vol. 60 , no. 4, pp. 575-608, 1996.

[86] H. Bolhuis, H. W. van Veen, B. Poolman, A. J. M. Driessen, and W. N. Konings, "Mechanisms of multidrug transporters," FEMS Microbiology Reviews, vol. 21, no. 1, pp. 55-84, 1997.

[87] J. P. Sarathy, V. Dartois, and E. J. D. Lee, "The role of transport mechanisms in Mycobacterium Tuberculosis drug resistance and tolerance," Pharmaceuticals, vol. 5, no. 11, pp. 1210-1235, 2012.

[88] C. Alvarez-Ortega, J. Olivares, and J. L. Martínez, "RND multidrug efflux pumps: what are they good for?" Frontiers in Microbiology, vol. 4, no. 7, pp. 1-11, 2013.
[89] A. Rojas, E. Duque, G. Mosqueda et al., “Three efflux pumps are required to provide efficient tolerance to toluene in Pseudomonas putida DOT-T1E," Journal of Bacteriology, vol. 183, no. 13, pp. 3967-3973, 2001.

[90] S. Geng, J. Fang, K. B. Turner, S. Daunert, and Y. Wei, "Accumulation and efflux of polychlorinated biphenyls in Escherichia coli," Analytical and Bioanalytical Chemistry, vol. 403, no. 8, pp. 2403-2409, 2012.

[91] A. Segura, A. Rojas, A. Hurtado, M. Huertas, and J. L. Ramos, "Comparative genomic analysis of solvent extrusion pumps in Pseudomonas strains exhibiting different degrees of solvent tolerance," Extremophiles, vol. 7, no. 5, pp. 371-376, 2003.

[92] J. F. Muller, The role of multidrug efflux pumps in the stress response of Pseudomonas aeruginosa to organic contamination, [Ph.D. thesis], Virginia Polytechnic Institute, Blacksburg, Va, USA, 2006.

[93] K. Poole, "Multidrug efflux pumps and antimicrobial resistance in Pseudomonas aeruginosa and related organisms," Journal of Molecular Microbiology and Biotechnology, vol. 3, no. 2, pp. 255263, 2001.

[94] C. Hunte and S. Richers, "Lipids and membrane protein structures," Current Opinion in Structural Biology, vol. 18, no. 4, pp. 406-411, 2008.

[95] M. A. Baboshin and L. A. Golovleva, "Aerobic bacterial degradation of polycyclic aromatic hydrocarbons (PAHs) and its kinetic aspects," Microbiology, vol. 81, no. 6, pp. 639-650, 2012.

[96] S. Kim, S. Seung-Youl, K. Kyung-Wook, H. Eun-Mi, and O. KyeHeon, "Proteomic analysis of the benzoate degradation pathway in Acinetobacter sp. KS-1," Research in Microbiology, vol. 154, pp. 697-703, 2003.

[97] L. Agulló, B. Cámara, P. Martínez, V. Latorre, and M. Seeger, "Response to (chloro)biphenyls of the polychlorobiphenyldegrader Burkholderia xenovorans LB400 involves stress proteins also induced by heat shock and oxidative stress," FEMS Microbiology Letters, vol. 267, no. 2, pp. 167-175, 2007.

[98] P. Martínez, L. Agulló, M. Hernández, and M. Seeger, "Chlorobenzoate inhibits growth and induces stress proteins in the PCB-degrading bacterium Burkholderia xenovorans LB400," Archives of Microbiology, vol. 188, no. 3, pp. 289-297, 2007.

[99] S. T. Hossain, I. Mallick, and S. K. Mukherjee, "Cadmium toxicity in Escherichia coli: cell morphology, Z-ring formation and intracellular oxidative balance," Ecotoxicology and Environmental Safety, vol. 86, pp. 54-59, 2012.

[100] T. Coba de la Peña, F. J. Redondo, M.F. Fillat, M. M. Lucas, and J. J. Pueyo, "Flavodoxin overexpression confers tolerance to oxidative beneficial soil improves survival in the presence of the herbicides paraquat and atrazine," Journal of Applied Microbiology, vol. 115, no. 1, pp. 236-246, 2013.

[101] S. Runkel, H. C. Wells, and G. Rowley, "Living with stress: a lesson from the enteric pathogen Salmonella enterica," Advances in Applied Microbiology, vol. 83, pp. 87-144, 2013.

[102] D. J. Gage and F. C. Neidhardt, "Adaptation of Escherichia coli to the uncoupler of oxidative phosphorylation 2,4-dinitrophenol," Journal of Bacteriology, vol. 175, no. 21, pp. 7105-7108, 1993.

[103] L. A. Lambert, K. Abshire, D. Blankenhorn, and J. Slonczewski, "Proteins induced in Escherichia coli by benzoic acid," Journal of Bacteriology, vol. 179, no. 23, pp. 7595-7599, 1997.

[104] Y.-S. Cho, S.-H. Park, C.-K. Kim, and K.-H. Oh, "Induction of stress shock proteins DnaK and GroEL by phenoxyherbicide 2,4-D in Burkholderia sp. YK-2 isolated from rice field," Current Microbiology, vol. 41, no. 1, pp. 33-38, 2000. 
[105] M. Hecker and U. Völker, "General stress response of Bacillus subtilis and other bacteria," Advances in Microbial Physiology, vol. 44, pp. 35-91, 2001.

[106] J. E. Visick and S. Clarke, "Repair, retold, recycle: how bacteria can deal with spontaneous and environmental damage to proteins," Molecular Microbiology, vol. 16, no. 5, pp. 835-845, 1995.

[107] P. M. Santos, D. Benndorf, and I. Sá-Correia, "Insights into Pseudomonas putida KT2440 response to phenol-induced stress by quantitative proteomics," Proteomics, vol. 4, no. 9, pp. $2640-$ 2652, 2004.

[108] A. Segura, P. Godoy, P. van Dillewijn et al., "Proteomic analysis reveals the participation of energy- and stress-related proteins in the response of Pseudomonas putida DOT-T1E to toluene," Journal of Bacteriology, vol. 187, no. 17, pp. 5937-5945, 2005.

[109] H. Keweloh, G. Weyrauch, and H.-W. Rehm, "Phenol-induced membrane changes in free and immobilized Escherichia coli," Applied Microbiology and Biotechnology, vol. 33, no. 1, pp. 6671, 1990.

[110] I. C. Sutcliffe, "Cell envelope composition and organisation in the genus Rhodococcus," Antonie van Leeuwenhoek, vol. 74, no. 1-3, pp. 49-58, 1998.

[111] C. E. Barry III and K. Mdluli, "Drug sensitivity and environmental adaptation of mycobacterial cell wall components," Trends in Microbiology, vol. 4, no. 7, pp. 275-281, 1996.

[112] H. Marrakchi, M.-A. Lanéelle, and M. Daffé, "Mycolic acids: structures, biosynthesis, and beyond," Chemistry and Biology, vol. 21, no. 1, pp. 67-85, 2014.

[113] R. Benz, "Uptake of solutes through bacterial outer membranes," in Bacterial Cell Wall, J. M. Ghuysen and R. Hakenbeck, Eds., pp. 397-420, Elsevier Science BV., Amsterdam, The Netherlands, 1994.

[114] H. C. Pinkart, J. W. Wolfram, R. Rogers, and D. C. White, "Cell envelope changes in solvent-tolerant and solvent-sensitive Pseudomonas putida strains following exposure to o-xylene," Applied and Environmental Microbiology, vol. 62, no. 3, pp. 11291132, 1996.

[115] S. Isken and J. A. M. de Bont, "Bacteria tolerant to organic solvents," Extremophiles, vol. 2, no. 3, pp. 229-238, 1998.

[116] S. A. Makin and T. J. Beveridge, "The influence of A-band and B-band lipopolysaccharide on the surface characteristics and adhesion of Pseudomonas aeruginosa to surfaces," Microbiology, vol. 142, no. 2, pp. 299-307, 1996.

[117] S. Kim and F. Picardal, "Microbial growth on dichlorobiphenyls chlorinated on both rings as a sole carbon and energy source," Applied and Environmental Microbiology, vol. 67, no. 4, pp. 19531955, 2001.

[118] B. Witholt, M.-J. De Smet, J. Kingma et al., "Bioconversions of aliphatic compounds by Pseudomonas oleovorans in multiple bioreactors: Background and economic potential," Trends in Biotechnology, vol. 8, no. 2, pp. 46-52, 1990.

[119] F. P. Chávez, F. Gordillo, and C. A. Jerez, "Adaptive responses and cellular behaviour of biphenyl-degrading bacteria toward polychlorinated biphenyls," Biotechnology Advances, vol. 24, no. 3, pp. 309-320, 2006.

[120] D. Halter, C. Casiot, H. J. Heipieper et al., "Surface properties and intracellular speciation revealed an original adaptive mechanism to arsenic in the acid mine drainage bio-indicator Euglena mutabilis," Applied Microbiology and Biotechnology, vol. 93, no. 4, pp. 1735-1744, 2012.
[121] T. Baumgarten, J. Vazquez, C. Bastisch et al., "Alkanols and chlorophenols cause different physiological adaptive responses on the level of cell surface properties and membrane vesicle formation in Pseudomonas putida DOT-T1E," Applied Microbiology and Biotechnology, vol. 93, no. 2, pp. 837-845, 2012.

[122] J. M. Diver, T. Schollaardt, H. R. Rabin, C. Thorson, and L. E. Bryan, "Persistence mechanisms in Pseudomonas aeruginosa from cystic fibrosis patients undergoing ciprofloxacin therapy," Antimicrobial Agents and Chemotherapy, vol. 35, no. 8, pp. 15381546, 1991.

[123] R. Aono and H. Kobayashi, "Cell surface properties of organic solvent-tolerant mutants of Escherichia coli K12," Applied and Environmental Microbiology, vol. 63, no. 9, pp. 3637-3642, 1997.

[124] S. Isken and J. A. M. De Bont, "Active efflux of toluene in a solvent-resistant bacterium," Journal of Bacteriology, vol. 178, no. 20, pp. 6056-6058, 1996.

[125] A. S. Rudolph, J. H. Crowe, and L. M. Crowe, "Effects of three stabilizing agents-proline, betaine, and trehalose-on membrane phospholipids," Archives of Biochemistry and Biophysics, vol. 245, no. 1, pp. 134-143, 1986.

[126] Ł. Chrzanowski, L. Y. Wick, R. Meulenkamp, M. Kaestner, and H. J. Heipieper, "Rhamnolipid biosurfactants decrease the toxicity of chlorinated phenols to Pseudomonas putida DOTT1E," Letters in Applied Microbiology, vol. 48, no. 6, pp. 756-762, 2009.

[127] D. R. Johnson, E. Coronado, S. K. Moreno-Forero, H. J. Heipieper, and J. van der Meer, "Transcriptome and membrane fatty acid analyses reveal different strategies for responding to permeating and non-permeating solutes in the bacterium Sphingomonas wittichii," BMC Microbiology, vol. 11, pp. 250256, 2011.

[128] C. C. C. R. de Carvalho, "Adaptation of Rhodococcus erythropolis cells for growth and bioremediation under extreme conditions," Research in Microbiology, vol. 163, no. 2, pp. 125-136, 2012.

[129] A. Kulp and M. J. Kuehn, "Biological Functions and biogenesis of secreted bacterial outer membrane vesicles," Annual Review of Microbiology, vol. 64, pp. 163-184, 2010.

[130] L. M. Mashburn-Warren and M. Whiteley, "Special delivery: vesicle trafficking in prokaryotes," Molecular Microbiology, vol. 61, no. 4, pp. 839-846, 2006.

[131] H. Kobayashi, K. Uematsu, H. Hirayama, and K. Horikoshi, "Novel toluene elimination system in a toluene-tolerant microorganism," Journal of Bacteriology, vol. 182, no. 22, pp. 6451-6455, 2000.

[132] T. J. Beveridge, S. A. Makin, J. L. Kadurugamuwa, and Z. S. $\mathrm{Li}$, "Interactions between biofilms and the environment," The FEMS Microbiology Reviews, vol. 20, no. 3-4, pp. 291-303, 1997.

[133] C. C. C. R. De Carvalho, L. Y. Wick, and H. J. Heipieper, "Cell wall adaptations of planktonic and biofilm Rhodococcus erythropolis cells to growth on $\mathrm{C}_{5}$ to $\mathrm{C}_{16}$ n-alkane hydrocarbons," Applied Microbiology and Biotechnology, vol. 82, no. 2, pp. 311320, 2009.

[134] G. Neumann, Y. Veeranagouda, T. B. Karegoudar et al., "Cells of Pseudomonas putida and Enterobacter sp. adapt to toxic organic compounds by increasing their size," Extremophiles, vol. 9, no. 2, pp. 163-168, 2005.

[135] Z. Zahir, K. D. Seed, and J. J. Dennis, "Isolation and characterization of novel organic solvent-tolerant bacteria," Extremophiles, vol. 10, no. 2, pp. 129-138, 2006.

[136] J. Fischer, U. Kappelmeyer, M. Kastner, F. Schauer, and H. J. Heipieper, "The degradation of bisphenol A by the newly 
isolated bacterium Cupriavidus basilensis JF1 can be enhanced by biostimulation with phenol," International Biodeterioration and Biodegradation, vol. 64, no. 4, pp. 324-330, 2010.

[137] L. Cao, Y. Gao, G. Wu et al., "Cloning of three 2,3-dihydroxybiphenyl-1,2-dioxygenase genes from Achromobacter sp. BP3 and the analysis of their roles in the biodegradation of biphenyl," Journal of Hazardous Materials, vol. 261, pp. 246-252, 2013.

[138] S. Zorádová-Murínová, H. Dudášová, L. Lukáčová et al., "Adaptation mechanisms of bacteria during the degradation of polychlorinated biphenyls in the presence of natural and synthetic terpenes as potential degradation inducers," Applied Microbiology and Biotechnology, vol. 94, pp. 1375-1385, 2012.

[139] H. Dudášová, L. Lukáčová, S. Murínová, and K. Dercová, "Effects of plant terpenes on biodegradation of polychlorinated biphenyls (PCBs)," International Biodeterioration \& Biodegradation, vol. 69, pp. 23-27, 2012.

[140] B. S. Hernandez, S.-. Koh, M. Chial, and D. D. Focht, "Terpeneutilizing isolates and their relevance to enhanced biotransformation of polychlorinated biphenyls in soil," Biodegradation, vol. 8, no. 3, pp. 153-158, 1997.

[141] E. K. Dzantor, J. E. Woolston, and B. Momen, "PCB dissipation and microbial community analysis in rhizosphere soil under substrate amendment conditions," International Journal of Phytoremediation, vol. 4, no. 4, pp. 283-295, 2002.

[142] S. H. Kwon, M. H. Hong, J. H. Choi et al., "Bioremediation of aroclor 1242 by a consortium culture in marine sediment microcosm," Biotechnology and Bioprocess Engineering, vol. 13, no. 6, pp. 730-737, 2008.

[143] S. Murínová, K. Dercová, and S. Murínová, "Bacterial cell membrane adaptation responses on stress caused with the environmental pollutants," Acta Chimica Slovaca, vol. 6, no. 1, pp. 106-114, 2013.

[144] M. M. Tajkarimi, S. A. Ibrahim, and D. O. Cliver, "Antimicrobial herb and spice compounds in food," Food Control, vol. 21, no. 9, pp. 1199-1218, 2010.

[145] A. Elaissi, K. H. Salah, S. Mabrouk, K. M. Larbi, R. Chemli, and F. Harzallah-Skhiri, "Antibacterial activity and chemical composition of 20 Eucalyptus species' essential oils," Food Chemistry, vol. 129, no. 4, pp. 1427-1434, 2011.

[146] A. K. Tyagi and A. Malik, "Antimicrobial potential and chemical composition of Mentha piperita oil in liquid and vapour phase against food spoiling microorganisms," Food Control, vol. 22, no. 11, pp. 1707-1714, 2011.

[147] P. M. Furneri, L. Mondello, G. Mandalari et al., "In vitro antimycoplasmal activity of citrus bergamia essential oil and its major components," European Journal of Medicinal Chemistry, vol. 52, pp. 66-69, 2012.

[148] M. Mendez, R. Rodríguez, J. Ruiz et al., "Antibacterial activity of plant extracts obtained with alternative organics solvents against food-borne pathogen bacteria," Industrial Crops and Products, vol. 37, no. 1, pp. 445-450, 2012. 

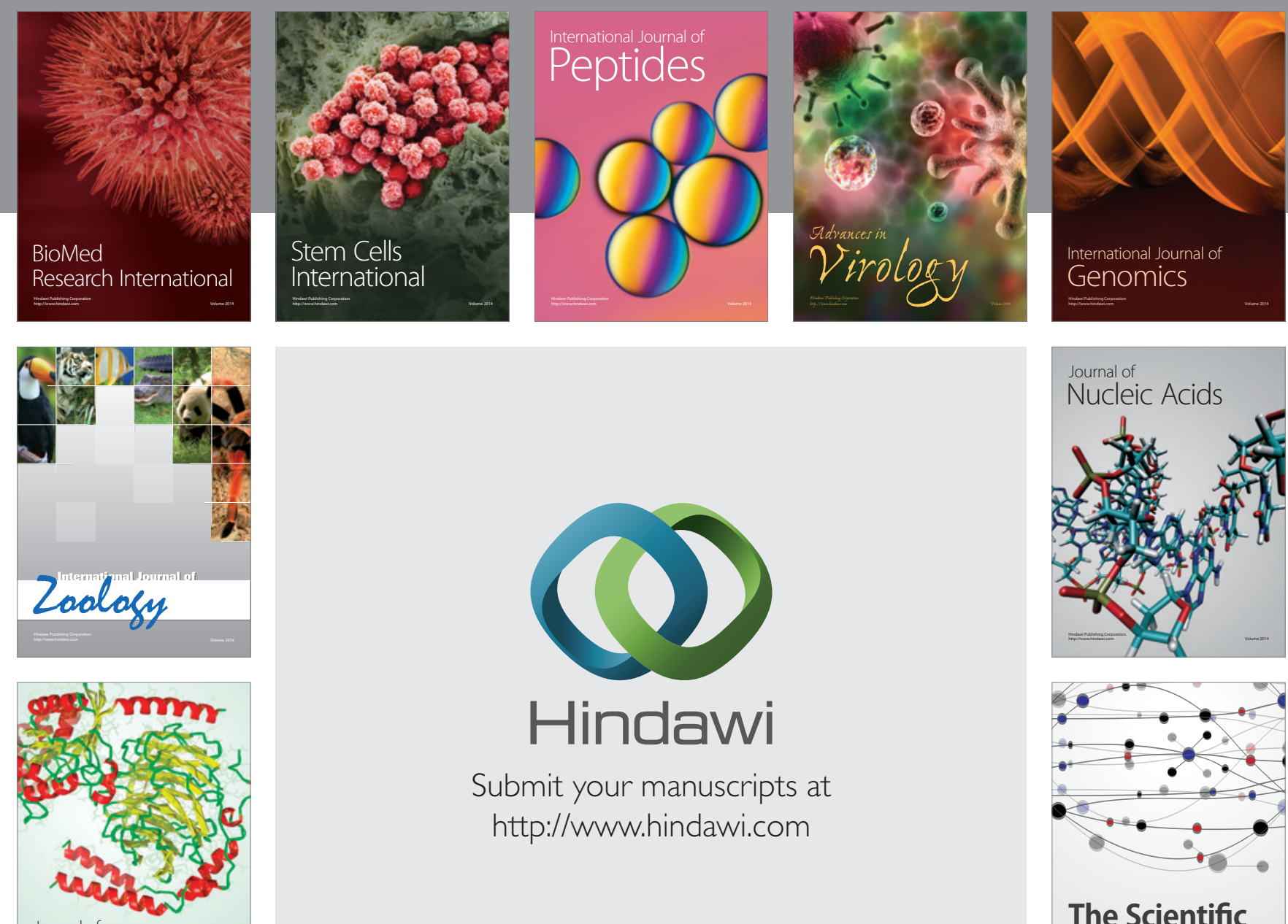

Submit your manuscripts at

http://www.hindawi.com

Journal of
Signal Transduction
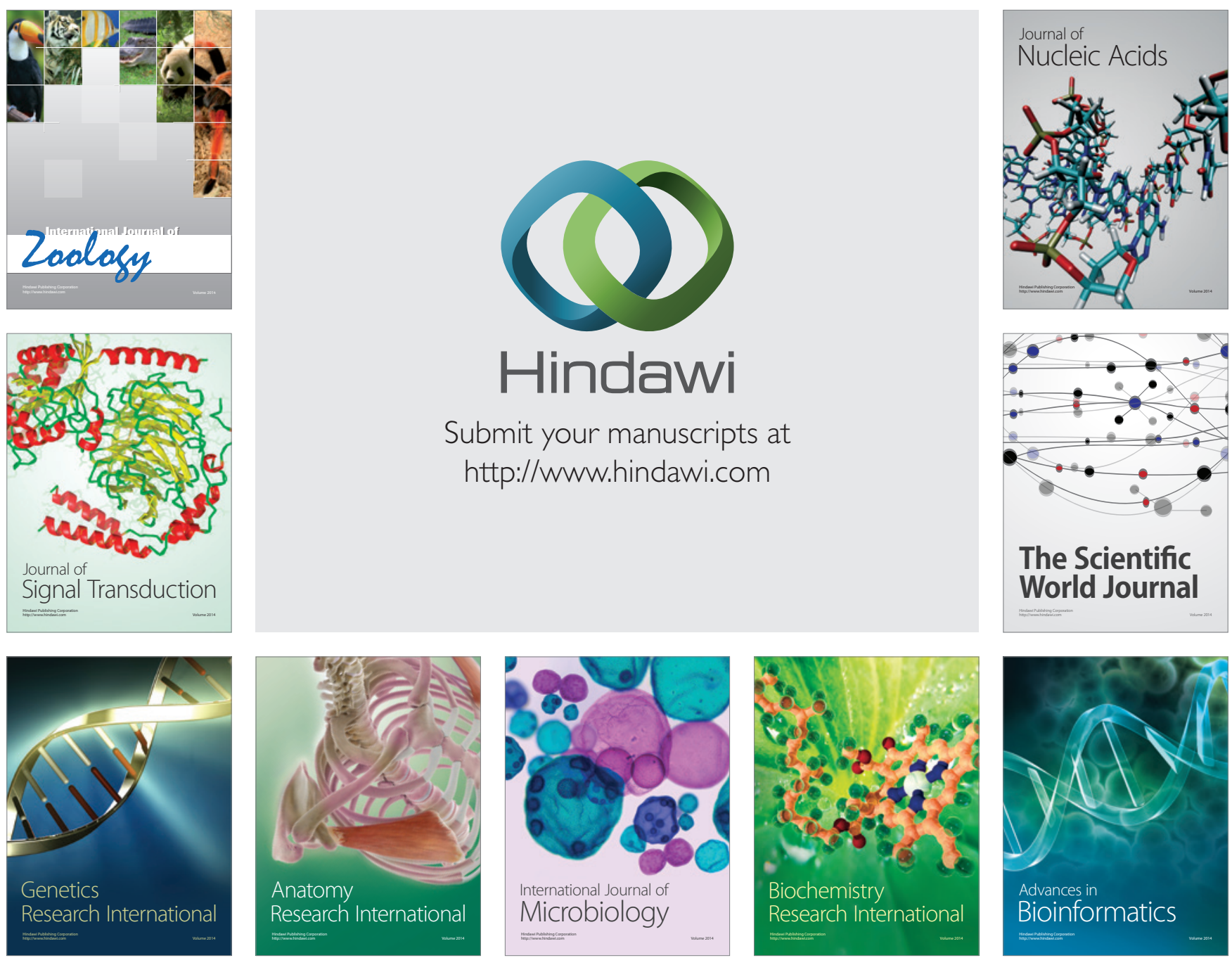

The Scientific World Journal
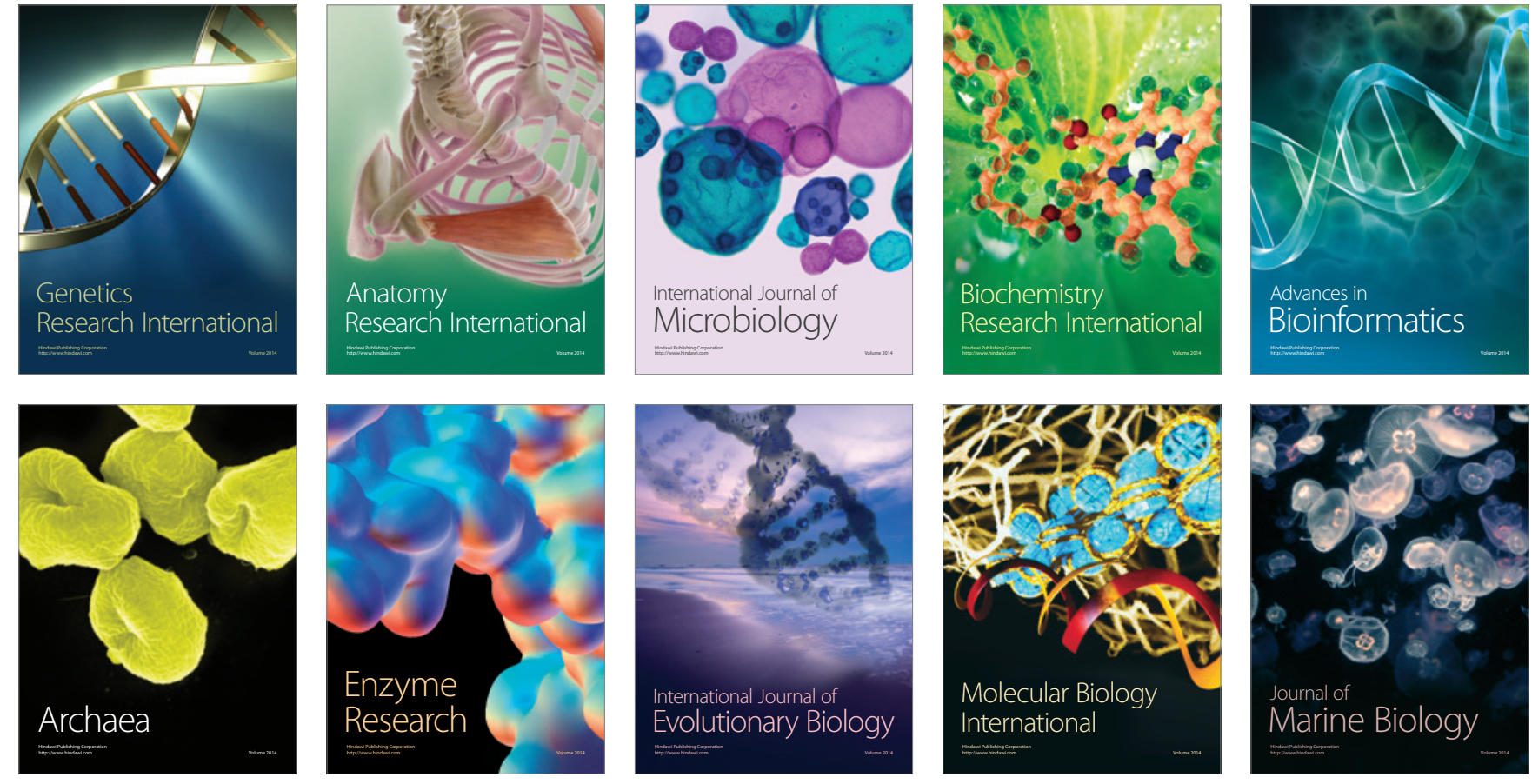